\title{
CORRUPTION, VOTING AND EMPLOYMENT STATUS: EVIDENCE FROM RUSSIAN PARLIAMENTARY ELECTIONS
}

\author{
Olga Popova
}
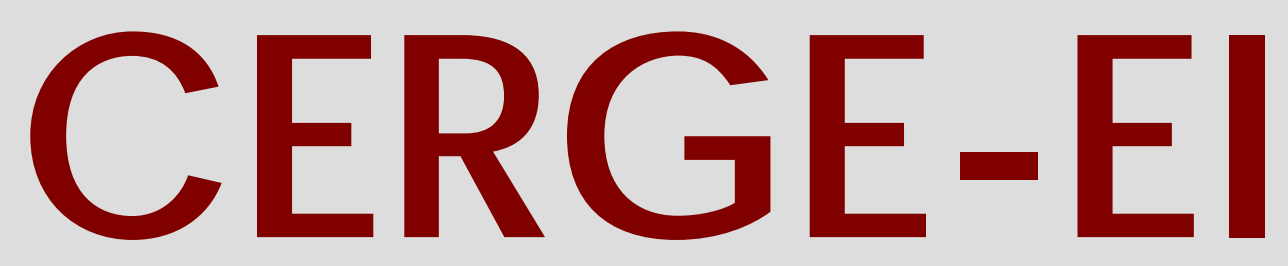

Charles University Centerfor Economic Research and Graduate Education Academy of Sciences of the Czech Republic Ec onomic s Institute 


\title{
Working Paper Series $\quad 428$ (ISSN 1211-3298)
}

\section{Corruption, Voting and Employment Status: Evidence from Russian Parliamentary Elections}

\author{
Olga Popova
}

CERGE-EI

Prague, December 2010 
ISBN 978-80-7343-229-4 (Univerzita Karlova. Centrum pro ekonomický výzkum a doktorské studium)

ISBN 978-80-7344-219-4 (Národohospodářský ústav AV ČR, v.v.i.) 


\title{
Corruption, Voting and Employment Status: Evidence from Russian Parliamentary Elections*
}

\author{
Olga Popova ${ }^{\dagger}$
}

\begin{abstract}
This paper examines to what extent the distribution of votes and voting behavior of people with different employment status are affected by regional differences in corruption. Using data from the Russian Parliamentary (State Duma) Elections 1999 and 2003, I develop and estimate a SUR system of equations which takes into account specific features of the Russian electoral system. The paper distinguishes between hard and perceived measures of corruption and analyzes the effects of corruption on the voting shares of particular parties and on voters' participation in elections. Additionally, a series of Monte Carlo simulations are performed to analyze the effects of corruption on the distribution of votes.
\end{abstract}

\begin{abstract}
Abstrakt
Tato práce zkoumá vliv regionálních rozdílů v míře korupce na výsledky hlasování a na volební chování lidí s různým postavením v zaměstnání. Analýzuji data z voleb do ruského parlamentu (do Státní Dumy) z let 1999 a 2003 a navrhuji SUR systém, který bere v úvahu specifické rysy ruského volebního systému. Článek rozlišuje mezi tvrdou a vnímanou mírou korupce a analyzuje dopady korupce na výsledky jednotlivých stran a na účast voličů ve volbách. Série Monte Carlo simulací jsou prováděny s cílem analyzovat vliv korupce na rozdělení hlasů mezi politickými stranami.
\end{abstract}

Keywords: corruption, economic voting, elections, employment status, Russia

JEL Classification: C31, D72, D73, E24

*This research has been supported by the CERGE-EI/World Bank Fellowship. I would like to thank Lubomir Lizal, Jan Kmenta, Jan Hanousek and Tatiana Kosyaeva for valuable comments and helpful suggestions. I am also grateful to Jan Fidrmuc, Byeongju Jeong, Stepan Jurajda, Gerard Roland (in alphabetic order) and participants at the 1st international Ph.D. student conference New Economic Challenges (Brno) for comments on earlier drafts of this paper. Many thanks go to Laura Strakova for her help with editing this paper. All errors remaining in this text are the responsibility of the author.

${ }^{\dagger}$ CERGE-EI is a joint workplace of the Center for Economic Research and Graduate Education, Charles University, Prague, and the Economics Institute of the Academy of Sciences of the Czech Republic. Address: CERGE-EI, P.O. Box 882, Politickych veznu 7, Prague 1, 111 21, Czech Republic. E-mail: Olga.Popova@cerge-ei.cz 


\section{Introduction}

Transition countries have experienced numerous interconnected economic, social and political reforms. However, weak law enforcement in these countries together with low democratization are likely to decrease reforms' credibility and politicians' accountability to voters and provide incentives for corruption (Tavares, 2007). ${ }^{1}$ Indeed, for most transition economies a high level of corruption has become a prominent feature (e.g., according to the Corruption Perception Index of Transparency International). Numerous studies concur that corruption has a negative impact on economic development and electoral results (among others, Rose-Ackerman, 1999; Svensson, 2005). Thus, studying the effects of corruption on economic and voting outcomes together with designing anticorruption policies and reducing corruption is a key condition for better economic development and growth in transition countries.

This paper closely investigates the effects of regional differences in corruption on electoral results in Russia and on the voting behavior of people with different employment status. As previous literature suggests, people with different employment status, namely the unemployed, and the employed in private and state sectors, have different income and employment prospects during transition period reforms and, thus, are likely to vote differently during elections, supporting or opposing reforms proposed by particular parties (Rodrik, 1995; Fidrmuc, 1998; Jackson et al., 2003; Grafstein, 2005). Previous studies on transition countries find that privately employed workers are more likely to support reforms, while state employed workers and the unemployed are more likely to oppose them (Fidrmuc, 1998, 2000a and b; Jackson et al., 2003). This research uses data from Russian Parliamentary (State Duma) Elections 1999 and 2003 to address the following question: does the voting behavior of people with different employment status depend on regional differences in corruption? The paper distinguishes between four groups of voters by their employment

\footnotetext{
${ }^{1}$ For the purposes of this research, I use the definition of corruption as "the use of public office for private gains", given by Bardhan (1997, p. 1321).
} 
status: the unemployed, privately employed, state employed (as is traditionally done in the literature on economic voting), and those out of the labor force (these voters have not yet been included in previous research). Along with an analysis of voting results, the effects of corruption and other factors on participation in elections are also analyzed. Such an analysis helps to understand better the factors that influence the distribution of voting outcomes in transition countries and have to be taken into account when implementing reforms.

To analyze the results of Russian Parliamentary Elections, I employ the SUR framework as proposed by Tomz et al.(2002) and extended by Jackson (2002). This paper accounts for a specific feature of the Russian electoral system, namely the option to vote "against all" parties. Along with the estimation of the SUR system, I perform statistical simulations of voting results for different corruption values: average corruption across regions, minimal corruption at all regions, and maximal corruption at all regions, and compare the results.

Two measures of corruption are used. The first one is traditional subjective perceptions about corruption, such as Corruption Perception Index of Transparency International measured for Russian regions. The second measure is the state capture index constructed by Slinko et al. (2005) and Yakovlev and Zhuravskaya (2009) for Russian regions. ${ }^{2}$ State capture is defined by the authors as legal privileges given by the regional government to the largest firms in the region and taking various forms of soft budget constraints. As Slinko et al. (2005) argue, a large state capture index represents high political power of the largest firms in a region. Firms with high political power are likely to seek the reelection of the current government and, thus, influence the voting choice of employees. Using two different measures of corruption also helps to do the evaluation of perceived and hard evidence about corruption. Recently, Olken (2009) attempted to evaluate hard and perceived measures of cor-

\footnotetext{
${ }^{2}$ Theoretical foundations for state capture were developed by Laffont and Tirole (1991). Hellman et al. (2000) and Hellman, Jones and Kaufmann (2003) study the dynamics and consequences of state capture in transition countries.
} 
ruption using Indonesian data and argued that since corruption perceptions are likely to have biases in measuring corruption, researchers and policymakers should not rely solely on corruption perceptions in the analysis of determinants of corruption. Such analysis of the effects of different measures of corruption on voting results will, thus, complement the evaluation of hard and perceived measures of corruption.

The findings show that even controlling for corruption, people with different employment status vote differently. Moreover, regional differences in corruption are indeed correlated with changes in the voting behavior of people with different employment status. Corruption positively influences participation in elections and also has indirect effects on the participation of people with different employment status. Using two different measures of corruption gives similar results for the analysis of voting outcomes.

The rest of the paper is organized as follows. The next section summarizes the literature relevant to this research. I then describe the methodological framework, data used, and results obtained. Section 6 concludes.

\section{Literature}

This section is divided into three parts. The first reviews theoretical and empirical studies that emphasize the different voting behavior of people with different employment status. The second addresses the effects of corruption on voting results and economic development. The third summarizes the relevant literature for Russia's economy.

\subsection{Employment Status and Different Voting Behavior}

The first attempt to identify economic groups who support or oppose reforms in transition economies was Rodrik (1995). In Rodrik's model, workers vote in favor or against state sector restructuring and privatization reform that implies reducing the 
level of subsidy paid to state employed workers and financed through the taxation of the private sector. Rodrik argues that whereas the privately employed always support such a reform, political support from the state employed depends on the timing of voting. During early transition voting, state employed workers support reforms since the probability of finding a higher-paid job in the private sector is high. During late transition voting, state employed workers oppose reforms and prefer to receive some state subsidy. The model has the unrealistic assumption of no unemployment in the post-transition period, and the unemployed in the model always support reforms since any subsidy decreases the growth of the private sector and, therefore, the probability of finding a job there. Fidrmuc (1998) further modified the model developed by Rodrik (1995), allowing for some level of unemployment after the transition and introducing unemployment benefits into the model. Under such, more realistic, assumptions the preferences of the unemployed and state employed workers are similar: during the early transition period they prefer a low subsidy whereas during the late transition period they no longer support reforms and prefer the highest possible subsidy. Fidrmuc (1998) also finds empirical support for theoretical predictions regarding only the voting preferences of the unemployed: there exists a negative relationship between support for reforms and the unemployment rate. Jackson et al. (2003), using data from Poland, have also shown empirically that the privately employed support parties proposing market-oriented reforms.

The role of unemployment in the process of reform implementation was also emphasized by Blanchard (1997), who argues that a high unemployment rate tends to block reforms, as both the unemployed and state employed workers would not support the restructuring reforms. The author further argues that introducing unemployment benefits into the model may change the results: under a certain level of wages in the state and private sector, the level of unemployment benefits, and probabilities to lose and find new jobs, the unemployed and state employed workers might support restructuring of the state sector. 
Grafstein (2005) emphasizes the reasons why the unemployed and employed vote differently: the unemployed and employed workers are initially different types of voters because of different initial income (unemployment benefits or wage) and different future employment prospects. In Grafstein's model the employment prospects of voters depend on the victory of a particular party during the election, i.e. a voter either receives or loses his/her job depending on election results. Grafstein emphasizes that if a so-called party of growth proposes to increase the probability of receiving a job for the unemployed and decrease the probability of losing it for the employed, then both groups are likely to support such a party. Empirical tests of the model using US data support the author's hypotheses about the voting decisions of the unemployed: they support the party of growth less if their education, their income, unemployment benefits, and unemployment rate are greater.

\subsection{Corruption, Voting and Economic Development}

Numerous studies confirm the negative impact of corruption on economic development (among others, Shleifer and Vishny, 1993; Mauro, 1995; Rose-Ackerman, 1999; Svensson, 2005). Shleifer and Vishny (1993) claim that additional distortions from corruption appear in an economy for two major reasons: the government's inability to prevent corruption due to the weakness of institutions, and the necessary secrecy of corruption. Unlike Shleifer and Vishny (1993) and other traditional research (for instance, Mauro, 1995) that understand corruption as one of the obstacles to economic growth, Basu and Li (1998) highlight that in transition economies corruption often coexists with reforms which are successfully improving a country's economic development. The strategy for implementing reforms, they argue, should allow for a temporary reduction in bureaucratic control so as to bring some benefits to corrupted bureaucrats and gain their support.

The impact of corruption on voting results has also been widely studied in political

literature. Rundquist, Strom and Peters (1977) suggest that corrupted candidates 
may still get support because voters either do not know about the cases of corruption, they ignore corruption, or they have some individual preferences for supporting a particular candidate even if this candidate is corrupt. Similarly, Peters and Welch (1980) point out that the reelection of corrupted candidates may happen for several reasons: imperfect information about a candidate being corrupt, voting for a corrupt candidate in exchange for some personal benefits, and, finally, voting for a corrupt candidate because of that candidate's membership in a party whose program the voter supports. The authors conlude that if a case of corruption is revealed, the corrupt candidate is likely to lose during the election up to 11 per cent of expected votes depending on the type of corruption. Welch and Hibbing (1997) support these numerical findings and argue that the negative impact of corruption is different for challenger and incumbent: voters tend to punish challengers more. Perrson et al. (2003) also find a negative relationship between the size of voting district and the level of political corruption. The authors point out that electoral rules also affect the level of corruption: corruption is less when candidates are elected individually rather than from party lists.

\subsection{Voting, Employment and Corruption in Russia}

Discussion of the specific features of Russian transition began with Leijonhufvud and Ruhl (1997) and increased greatly after the famous keynote address by Stiglitz (1999) who underscored the contrast between China and Russia in the implementation of reforms. China, which chose its own transition path without relying on western advisors, started transition with a relatively low GDP yet ended up after the transition with high GDP growth and the rapid creation of the privately-owned enterprise sector. The Russian transition, in contrast, followed the recommendations of international institutions (the so-called "Washington consensus"). During its transition the Russian GDP decreased substantially. "Spontaneous" privatization in Russia led to a decrease in investments. Stiglitz (1999) argued that the primary reason for such 
differences in China and Russia is Russia's failure to understand the basic principles of market economy functioning and reform implementation. Russian reform-makers concentrated on the justification for particular reforms but without a proper understanding of how to gain public support for these reforms. This characterized the specifics of Russian transition. Stiglitz thus concluded that without a proper reform strategy, the implementation of reforms cannot be successful.

Few studies have attempted to empirically estimate public support for economic reforms in Russia. Warner (2001) examines differences in the support for price liberalization and small-scale privatization across Russian regions during the Parliamentary elections in 1995. Although economic reforms towards a market economy were not unpopular in the Russian regions, the average level of support for parties associated with market reforms was not high. The author also points out that the intensity of reforms' implementation positively influenced the support for reforms. Another study of Russian public support for economic reforms was done by Frye (2006) who, using firm-level survey data from eight Russian regions, investigates how political support for four market-oriented parties depends on the creation of new workplaces in the country. Managers of fast-developing private enterprises are more likely to support market-oriented parties so as to avoid extra regulations and costs on hiring a workforce. Similarly, privately and state employed workers are more likely to have different voting preferences. This conclusion supplies a rationale for why employment in enterprises with different ownership should be taken into account when estimating the political support for economic reforms in Russia.

Various impacts of corruption on the Russian economy have also been analyzed in the literature. As Safavian et al. (2001) argue, corruption in Russia has a negative impact on economic growth and investment activities and prevents the development of small enterprises in Russia. Dininio and Orttung (2005), using corruption perceptions data, analyze regional differences in corruption between Russian regions. The authors emphasize the role of political, social, institutional, and structural factors in 
explaining regional variation in corruption. Slinko et al. (2005) and Yakovlev and Zhuravskaya (2009) highlight that high corruption is an obstacle to the development of small and medium enterprises in Russia. Using constructed data on Russian state capture, the authors argue that large firms which receive privileges from the regional government tend to be profitable and faster developing. A high state capture index reflects the political influence of large firms and implies worse performance for small businesses and firms without privileges.

To summarize, corruption has been characterized in the literature as a significant factor influencing voting results and economic development. Yet previous studies analyzing the voting behavior of people with different employment status do not account for corruption as a factor that may influence their voting behavior. The econometric model for analyzing multiparty elections constructed in this research enables an analysis of the effect of corruption on voting behavior of people with different employment status, distinguishing between four groups of voters: the unemployed, privately employed, state employed, and those out of the labor force.

\section{Methodological Framework}

\subsection{Specific Features of Russian Parliamentary Elections}

According to the Constitution of the Russian Federation, Russian Parliament, the Federal Assembly, has two chambers, the Council of the Federation and the State Duma. The Council of the Federation is formed from the representatives of legislative and executive authorities from each region. The State Duma consists of 450 deputies who are elected for four years: 225 of them are elected from federal lists of candidates proposed by political parties proportionally to the vote share received by a party during parliamentary elections; the other 225 deputies are elected by majority voting for one particular candidate from each out of 225 voting districts in Russia (Federal Law \# 175-FZ). In this research we analyze the voting outcomes of political parties 
during parliamentary elections, and, thus, use data only on the voting results from federal lists of candidates.

Apart from voting for particular candidates (federal lists of candidates), the Russian electoral system has a specific feature, namely the option to vote "against all" candidates. The option to vote "against all" is an explicit form of protest voting against all candidates which is available in the Russian Federation at elections at all administrative levels and has already become a basic element in the Russian Electoral system. "Against all" not only regularly receives a comparatively large share of votes but even has its own unofficial electoral campaign on behalf of the opponents of reforms (Oversloot et al., 2002). For instance, during the Russian parliamentary (State Duma) election 2003 the option "against all" received almost enough votes to be "elected" to Parliament: "against all" received $4.7 \%$, while a party is required to receive $5 \%$ of all votes to be elected. This share was greater than that of 19 of 23 parties participating in the election. ${ }^{4}$ For comparison, at the State Duma election 1995 the share of votes "against all" was greater than the share of 33 out of 43 parties, in 1999, 20 out of 26 (Oversloot et al., 2002). This evidence indicates that the option "against all" plays a significant role in Russian elections and should thus be included into the analysis.

According to Russian legislation, a party which receives more than 5 percent of all votes is elected to Parliament. ${ }^{5}$ During the 2003 parliamentary election in total 23 political parties participated though only four of them were elected to Parliament. During the 1999 parliamentary election 26 parties participated and 6 of them were elected. Table 1 presents the results of 1999 and 2003 and a short description of the main parties participating.

\footnotetext{
${ }^{3}$ According to The Federal Law of the Russian Federation \#107-FZ of July 12, 2006 this option has been cancelled. However, in the analysis of the 1999 and 2003 parliamentary elections this option should be taken into account.

${ }^{4}$ According to the statistical data from the Russian Parliamentary Election 2003 "Vote Return in Federal Electoral District", available online from http://gd2003.cikrf.ru/gdrf4_engl.html

${ }^{5}$ On the Election of Deputies of the State Duma of the Federal Assembly of the Russian Federation, Federal Law of the Russian Federation No.175-FZ of December 20, 2002.
} 
I analyze the voting results for those parties which were elected to Parliament during the parliamentary elections 1999 and 2003 (i.e. received more than 5 percent) or received more than 3.5 percent of votes. Since the list of parties participating in the 1999 and 2003 elections is slightly different, I include different parties into the analysis of the 1999 and 2003 voting results. The following parties are within the scope of analysis for the 2003 election: Political Party "United Russia", Communist Party of the Russian Federation (CPRF), Liberal Democratic Party of Russia (LDPR), National-Patriotic Union "Rodina" ("Motherland"), Russian Democratic Party "Yabloko" ("Apple"), "Union of Right Forces", and the number of votes cast against all federal lists of candidates. For the 1999 election I analyze the results for parties "Interregional Party "Yedinstvo", Communist Party of the Russian Federation (CPRF), Liberal Democratic Party - Zhirinovsky block, voting block "Otechestvo-All Russia", Russian Democratic Party "Yabloko" ("Apple"), "Union of Right Forces", and the number of votes cast against all federal lists of candidates. In both the 1999 and 2003 analyses, the returns to all other parties participating in elections are grouped into a category referred to as "other", satisfying the constraint that all vote shares sum to one.

\subsection{The Model}

In a model for the analysis of voting outcomes one has to account for two electoral data features. First, each vote share falls within the interval between zero and one, and, second, all vote shares sum up to one (King, 1990; Katz and King, 1999). This means that vote shares of parties are dependent on each other. This is important for the choice of estimation method.

Different methods have been proposed for the estimation of the voting outcomes model. As Katz and King (1999) point out, an ordinary least squares (OLS) regression is not applicable for the analysis of voting outcomes since it requires a potentially unbounded dependent variable. For the analysis of multiparty elections the authors 
propose a method which requires multivariate logistic data transformation and then the likelihood maximization of multivariate $t$ distribution. The obvious disadvantage of such a method, as the authors concede, is that it is hard to apply to the case of more than three parties due to difficulties in computations.

Tomz, Tucker, and Wittenberg (2002), based on Zellner's (1962) seemingly unrelated (SUR) method, propose a modification to Katz and King's model. The SUR method jointly estimates equations for all parties participating in elections and links equations only by their disturbances (Greene, 2003). The observed voting share of each party has the form of multinomial logit (MNL). This method is suitable when an individual chooses one alternative from a group of choices (Wooldridge, 2002). This accurately represents voters' decisions in multiparty elections. Following Katz and King (1999), Tomz et al. (2002) apply multivariate logistic transformation to convert observed voting shares from the unit interval to an unbounded scale: take the natural logarithm of each party's voting share relative to the share of the base party. The received vector of log-ratios for each voting district is assumed to be multivariate normally distributed. Further, the feasible generalized least squares (FGLS) technique (as described, e.g., by Greene, 2003) is applied for the SUR system of regression equations of log-ratios of voting share on the set of explanatory variables. Tomz et al. (2002) point out that the estimates of coefficients also could be obtained by separate regressions for each party, but SUR is a more efficient method. The authors note that such a model is applicable for the analysis of any kind of data in which the outcome variables are nonnegative and sum up to unity.

Jackson (2002), extending the analysis done by Tomz et al. (2002), gives a detailed description of the model and estimates the proposed model on data from the 1993 Polish Parliamentary election. The statistical model proposed by Jackson (2002) can be used for the analysis of any number of parties. The author pays special attention to the error term and the description of distributional assumptions.

The approach proposed and developed by Tomz et al.(2002) and extended by 
Jackson (2002) is applicable for the analysis of the Russian Parliamentary elections because it allows the analysis of multiparty elections and is relatively simple in computations, both of which are important for transforming and estimating the large dataset of Russia.

In line with Tomz et al. (2002) and Jackson (2002), I first perform the MNL transformation of the dependent variable which is each party's vote share:

$$
\begin{aligned}
Y_{i} & =\left[\ln \left(\frac{V_{i 1}}{V_{i J}}\right), \ln \left(\frac{V_{i 2}}{V_{i J}}\right), \ldots, \ln \left(\frac{V_{i j}}{V_{i J}}\right)\right], \text { where } \\
i \text { regions, } i & =1,2, \ldots I ; j \text { parties, } j=1,2, \ldots, J-1 .
\end{aligned}
$$

Therefore, we have the vector $Y_{i}$ of $J-1 \log$-ratios $Y_{i j}=\ln \left(\frac{V_{i j}}{V_{i J}}\right)$, for each party $j$ relative to base party $J$. It is assumed that the vector $Y_{i}=\left[Y_{i 1}, \ldots, Y_{i(J-1)}\right]$ follows multivariate normal distribution with mean vector $m_{i}$ and variance matrix $\sum$. Like Tomz et al. (2002), I model $m_{i}$ such that $m_{i}=\left[x_{i 1} \beta_{1}, x_{i 2} \beta_{2}, \ldots, x_{i(J-1)} \beta_{(J-1)}\right]$, i.e., as a linear function of explanatory variables $(x)$ and coefficients $(\beta)$.

The observed vote share $V_{i j}$ that party $j$ receives in region $i$ during the elections has the form

$$
V_{i j}=\operatorname{Pr}(\text { voters in region } i \text { choose party } j)=\frac{\exp \left(Y_{i j}\right)}{\sum_{j=1}^{J-1} \exp \left(Y_{i j}\right)}
$$

and $V_{i J}$ stands for the vote share that base party $J$ receives in region $i$ during the elections. $V_{i j} \in[0,1]$ for all $i$ and $j, \sum_{j=1}^{J} V_{i j}=1$ and for all $i$.

To transform the data on vote shares, I choose a base party to use as a benchmark for comparison. For both the 1999 and 2003 elections I have 8 categories to estimate: 6 major parties, category "other", and the number of votes "against all". 6 The

\footnotetext{
${ }^{6}$ On the methodological level it would be worth comparing the results from the model with the "against all" option (i.e., estimated using the data from the 1999 and 2003 elections) and without the "against all" option (2007 election). However, the data on regional corruption after 2003 are not available for this purpose. As mentioned by Dininio and Orttung (2005), regional data on the Corruption Perception Index in Russia have been collected by INDEM after 2003, but have not been published due to inconsistency with previous findings.
} 
category "other" is chosen as a base party and stands for the sum of all vote shares of all other (17 in the case of the 2003 election and 20 in the case of the 1999 election) parties participating in the election.

After the transformation, I construct the SUR system of linear regression equations. It has 7 linear equations to account for the major parties and "against all" option:

$$
\begin{aligned}
& Y_{i 1}=\ln \left(\frac{V_{i 1}}{V_{i b}}\right)=f\left(\text { Corr }_{i}, \text { State }_{i}, \text { Pr } \text { ivate }_{i}, \text { Out }_{i}, \text { Interact }_{i}, \mathbf{X}_{i 1}, \varepsilon_{i 1}\right) \\
& Y_{i 2}=\ln \left(\frac{V_{i 2}}{V_{i b}}\right)=f\left(\text { Corr }_{i}, \text { State }_{i}, \text { Pr } \text { ivate }_{i}, \text { Out }_{i}, \text { Interact }_{i}, \mathbf{X}_{i 2}, \varepsilon_{i 2}\right) \\
& Y_{i 7}=\ln \left(\frac{V_{i 7}}{V_{i b}}\right)=f\left(\text { Corr }_{i}, \text { State }_{i}, \text { Pr } \text { ivate }_{i}, \text { Out }_{i}, \text { Interact }_{i}, \mathbf{X}_{i 7}, \varepsilon_{i 7}\right),
\end{aligned}
$$

where $V_{i j}$ is the vote share that party $j$ receives in region $i ; \operatorname{Corr}_{i}$ is the level of corruption in region $i$ measured either by state capture index or integral corruption perception index (integral CPI); State $i_{i}$ is the number of workers employed in the state sector in region $i$; Private $_{i}$ is the number of workers employed in the private sector in region $i$; Unem $_{i}$ is the number of the unemployed in region $i$; Out $t_{i}$ is the number of people out of the labor force in region $i$; Interact $_{i}$ is the set of interaction terms between $\operatorname{Corr}_{i}$ and State $_{i}$, Private $_{i}$, Unem $_{i}$, and $O u t_{i} ; \mathbf{X}_{i j}$ is the set of regional characteristics that may influence the votes for particular parties, such as the real gross regional product (GRP) per capita, the number of students and pensioners, the share of urban population, and the number of registered voters in the voting district; and $\varepsilon_{i j}$ is the error term. The error terms are correlated across the equations since the dependent variable is constructed from the voting shares of parties and a higher log-ratio for one party implies a lower log-ratio for the others.

Coefficient estimates from the SUR system show how a 1-unit change in some explanatory variable affects the log-ratio for a particular political party. For the interpretation of results, in particular voting shares, it is necessary to calculate a 
new set of $Y \mathrm{~s}$ based on real or hypothetical values for $X \mathrm{~s}$ and coefficient estimates, and then convert $Y$ 's back to voting shares by reversing the logit transformation. However, the signs of the coefficients on particular variables in the SUR system can be interpreted as support (positive sign) or opposition (negative sign) to a particular political party in comparison with the vote share of "other" parties.

This paper also estimates the SUR system and then performs statistical simulations of voting results for different corruption values: average corruption across regions, minimal corruption in all regions, and maximal corruption in all regions, and compares the results. Monte Carlo simulations of voting results have been performed using the methodology and software CLARIFY developed by King et al. (2000) and Tomz et al. (2001, 2002). First, I estimate parameters of the SUR system and then draw 1000 simulations of those parameters $(\boldsymbol{\beta}$ 's $)$ from the multivariate normal distribution. After that I set hypothetical values for the explanatory variables (the $\mathbf{X}_{\mathrm{s}}$ ). To analyze the different impact of corruption on voting results, I consequently set each corruption measure to its mean across the regions, maximum across the regions, and minimum across the regions. All other explanatory variables are set at their mean. Then, based on chosen values of $\mathbf{X}_{\mathbf{s}}$ and on the parameters $\boldsymbol{\beta}$ that were generated at the first stage, I simulate predicted vote shares for each party.

The main hypotheses that I test in this paper are as follows.

$H_{1}$ : regional differences in corruption do not influence voting results versus $H_{a 1}$ that regional differences in corruption influence voting results;

$H_{2}$ : when regional corruption is controlled for in the model, people with different employment status vote similarly versus $H_{a 2}$ that when regional corruption is controlled for in the model, people with different employment status vote differently;

$H_{3}$ : corruption does not influence the voting choice of people with different employment status versus $H_{a 3}$ that corruption influences the voting choice of people with different employment status.

Simulations also allow looking at changes in voting shares for all parties if cor- 
ruption level changes.

To complete the analysis of voting results, I also examine the participation in elections since the reasons which drive people to participate in elections may also affect their decision to vote for a particular party. For the analysis of participation in elections I run OLS using the following linear specification:

Participation $_{i}=f\left(\right.$ Corr $_{i}$, State $_{i}$, Pr ivate $_{i}$, Out $_{i}$, Interact $\left._{i}, \mathbf{X}_{i}, \mu_{i}\right)$, where

Participation $_{i}$ is the number of voters in region $i$ participating in the elections; Corr $_{i}$, State $_{i}, \operatorname{Pr}$ ivate $_{i}$, Out $_{i}$, Interact $_{i}, \mathbf{X}_{\mathrm{i}}$ are the same variables as described above and used for the analysis of voting results; and $\mu_{i}$ is the error term.

The main hypothesis is that $\left(H_{4}\right)$ corruption does not influence participation in elections. I also test $\left(H_{5}\right)$ that corruption has no direct impact on voting participation and $\left(H_{6}\right)$ that corruption has no indirect impact through the effect of corruption on people's decision to participate. To test whether corruption influences the decision of people with different employment status to participate in elections, I include interaction terms into the regression.

\section{Data}

For the purposes of this research I use data from several sources. The first source is the Central Election Commission of the Russian Federation. Detailed results (in Russian) of the Russian parliamentary election of 1999 and 2003 from each region and summary statistics of the election (both in English and Russian) were obtained from the web page of the Central Election Commission. These data give statistics on each out of 225 voting districts in Russia: the number of voters on the voter lists, the number of ballots received, the number of votes received in favor of each party, 
and the number of votes received against all parties. ${ }^{7}$

The second source of data is the publication "Regions of Russia" from the Russian State Statistical Office. This source contains statistical information on the social and economic development of every region of the Russian Federation (republics, territories, regions, cities of the federal subordination, autonomous regions and autonomous areas), including data on employment and unemployment, money income and consumer expenditures of the population, and other indicators.

I use the regional level data on corruption in Russia that come from two sources. ${ }^{8}$ The first is the survey of Transparency International-Russia (TI-Russia) and the Information for Democracy Foundation (INDEM) on measuring corruption in Russian regions conducted in 2002. ${ }^{9}$ It is a cross-sectional data set based on subjective perceptions. Both individuals (representing about $73 \%$ of the total Russian population) and entrepreneurs (mostly small and medium size enterprises; large businesses are underrepresented) are asked about various indicators of corruption. Different indices are constructed to account for business (for entrepreneurs) and everyday (for individuals) corruption, including an integral index of corruption perception, integral index of corruption amount, individuals' and entrepreneurs' corruption perception indices, and indices of trust in authority. Business corruption indices are divided into three correlated categories: administrative corruption (extortion), state capture (legal preferential treatment of business by government), and business capture (illegal government control on business). Integral CPI ranges from zero to one with zero value reflecting the highest corruption perceptions. ${ }^{10}$ Unlike the CPI computed by Transparency International at the country level which uses the assessments of cor-

\footnotetext{
${ }^{7}$ According to Federal Law \#67-FZ a voting district is determined by electoral commission on the basis of the number of registered voters on a certain territory. More populated regions typically include more than one voting district during elections. The number of voting districts (225) is, thus, greater than the number of Russian regions (83).

${ }^{8}$ Since the data on corruption are avalable for Russian regions, not for voting districts, I assume that all voting districts within one region have the same corruption level.

${ }^{9}$ The use of data for the year 2002 for the analysis of elections in 2003 is justified since according to Transparency International, the CPI scores and ranking of Russia are the same in 2002 and 2003.

${ }^{10}$ For the purposes of comparison with results obtained using the state capture index, I transform integral CPI so that its value equal to one stands for high corruption, and zero for low corruption.
} 
ruption from the preceding 2-3 years for the index computation, the CPI in Russian regions used in this paper includes the assessments of corruption over one year only (Transparency International and INDEM Foundation, 2002).

The second data source for corruption is the data on state capture index, i.e. the index for "preferential treatment" of largest firms in regions, taken from Slinko, et al. (2005) and Yakovlev and Zhuravskaya (2009). The index is constructed in the form of a Herfindahl-Hirschman index of concentration with zero value standing for low concentration of preferential treatment of large firms (low corruption), and one for high concentration (high corruption). The authors count the number of cases when the regional government legislatively allowed the largest firms in a region to have a soft budget constraint in the form of soft taxation or soft subsidization. The five largest firms in each region are selected according to the largest volume of sales in a given year and if this firm had been treated preferentially at least once. The state capture index data is a panel constructed from regions of Russia between 1992-2003.

All the descriptive statistics for the data used in the research can be found in the appendix (Tables 2-5). For estimation purposes, voting shares are transformed according to the methodology presented above. Each dependent variable has 225 observations for the 2003 election and 224 observations for the 1999 election according to the number of voting districts in Russia. The data on some explanatory variables are missing: the Chechen Republic (due to the inability to collect data during the military conflict) and national territories (nacionalnye okruga) within larger Russian regions. Also, given the availability of the data on corruption, I reduce the number of voting districts taken into the analysis. Since the data on regional corruption perception index are not available for 1999, for the analysis of the 1999 parliamentary election only the data on state capture are used. 


\section{$5 \quad$ Results and Discussion}

The results of two empirical specifications for the 2003 election are summarized in Tables 6-8. Table 6 presents the results of the model where the state capture index was used as the measure of corruption. Respectively, Table 7 presents the results of the model where the corruption perception index was used. In both tables the columns present the results for a particular party. Explanatory variables are given in rows. Into Table $8 \mathrm{I}$ include the results when both measures of corruption are included in order to evaluate them.

The results of the 1999 election are presented in Table 9. In Table 10 I summarize the results for the estimation of participation in elections. Tables 11-15 include artificial voting results for the 1999 and 2003 elections.

While analyzing the post-transition period in Russia, it is difficult to distinguish clearly between "market-oriented" and "not market-oriented" parties as it is usually done in the literature on economic voting in transition countries (for instance, Rodrik, 1995; Fidrmuc, 1998; Jackson et al., 2003), and, thus, determine their support or opposition by the electorate. Titkov (2004) proposed an elegant two-dimensional classification for Russian parties during parliamentary elections. As he suggests, there can be two dimensions: "reformist-conservative" and "conformist protest". The first dimension includes the "Union of Right Forces" and "Yabloko" as the reformist parties and the Communist and Agrarian Parties as the conservative ones. The second dimension includes the "conformist" party of power ("United Russia" in 2003 and "Otechestvo" in 1999) against the protest Liberal Democratic Party (LDPR). Titkov's (2004) classification has also been used by Austin et al. (2005). For simplicity in the interpretation of results, this paper considers only the second, i.e. "conformistprotest", dimension. $^{11}$ I refer to the "party of power", or a status-quo party, as

\footnotetext{
${ }^{11}$ Titkov (2004), using the main components analysis, argues that the two dimensions explain the 50\% variation in the 1999 and 2003 results. The second, "conformist-protest", dimension explains about $36 \%$ of the variation, both in the 1999 and 2003 elections, which is higher than the role of the first dimension (16\% in 1999 and 14\% in 2003). Moreover, Titkov (2004) points out that the role of the "conformist-protest" dimension is increasing. Thus, the choice of "conformist-protest"
} 
the party which is associated with the current government before the elections of new parliament. In 2003, the party "United Russia" played the role of the "party of power". All other parties I define as "opposition to the party of power". In 1999, both "Yedinstvo" and "Otechestvo-All Russia" positioned themselves as pro-government parties, though during the election the Communist Party received the highest number of votes with "Yedinstvo" coming in second, and "Otechestvo-All Russia" third.

\subsection{Corruption and Voting Results}

The literature reviewed above suggests some dependence between corruption and voting results. However, it should be pointed out that previous literature (Rundquist, Strom and Peters, 1977; Peters and Welch, 1980) has been concerned about particular cases of corruption that are revealed and their effects on the outcome of voting for particular candidates. This paper takes into account regional differences in corruption and analyzes their effects on the outcome of state level elections. In all empirical specifications for most of the parties (except for Liberal Democratic Party in the 2003 election when state capture is used, "Yedinstvo" and Communist Party in the 1999 election) regional differences in corruption negatively influence voting results. This result holds in both cases: when I use either state capture, or integral CPI as a corruption measure, though the result is not significant for some parties. Both corruption measures also negatively influence the voting results of "against all" option: when corruption rises, people are less likely to vote against all parties. This result is intuitive: if corruption is increasing, non-ignorant voters are likely to think that they can change the situation by voting for some party instead of voting against all parties.

for closer analysis in this paper is justified. 


\subsection{Employment Status and Voting Results}

In this section I analyze the findings regarding the voting behavior of people with different employment status when controlling for corruption.

When state capture (Table 6) or both corruption measures (Table 8) are used, I find that the unemployed during the 2003 election supported most of the parties, though when only state capture is used the result is significant only for "United Russia" and the option "against all" parties. When the integral CPI is used to control for corruption in the 2003 election (Table 7), the unemployed support the "Union of Right Forces" only; for the rest the result is not significant. In the 1999 election (Table 9) the unemployed also support most of the parties (except "Otechestvo"). To recall, previous literature argues that the unemployed workers may either support or oppose pro-refrom parties depending on the timing of elections (Fidrmuc, 1998) or on the existence of a social security net (Blanchard, 1997). Since both 1999 and 2003 belong to the late transition period by which time the social security net had been already developed to a certain extent, these results are in line with the previous findings even when controlling for corruption.

State employees oppose most of the parties. This is an expected result since, as previous research suggests, state employees are likely to oppose reforms in late transition (Fidrmuc, 1998). The coefficient on the state employed variable is negative and significant for "Rodina" and "against all" in the 2003 results when state capture is used; for the Communist Party, "Rodina", "Yabloko", the "Union of Right Forces", and "against all" in the 2003 results when integral CPI is used; for "Rodina" and "against all" in the 2003 results when both measures are used; and for "Yabloko" and the "Union of Right Forces" in the 1999 results. Notably, the coefficient on the state employed is negative, but insignificant for the party of power "United Russia" in all specifications for the 2003 election.

The privately employed oppose the party of power "United Russia" in the 2003 election. The result is significant when state capture is used and when both measures 
are used to control for corruption (the coefficient is negative, but insignificant when integral CPI is used). These results may seem contradictory to previous literature (Rodrik, 1995; Fidrmuc, 1998; Jackson et al., 2003) that suggests that privately employed workers are likely to support market-oriented parties of power. However, since it is difficult to distinguish clearly between 'market-oriented' and 'not marketoriented' parties in Russia, privately employed workers may oppose the party of power but not necessarily oppose market-oriented reforms. When state capture is used, the privately employed support the Liberal Democratic Party in the 2003 election. When integral CPI is used, the privately employed support the Communist Party and oppose "Rodina" and "against all" in the 2003 election. When both measures are used, the privately employed support the Communist Party, the Liberal Democratic Party, and the "Union of Right Forces" in the 2003 election. In the 1999 election the privately employed oppose "Otechestvo"; for all other parties the result is not significant.

People who are out of the labor force support the party of power "United Russia" in all specifications for the 2003 election. When state capture is used, they also support the "Union of Right Forces" and oppose the Liberal Democratic Party and "against all" option in the 2003 election. When integral CPI is used, those who are out of the labor force oppose the Communist Party and the "Union of Right Forces" in the 2003 election. When both measures are used, they oppose "Rodina", "Union of Right Forces" and "against all" option in the 2003 election. In the 1999 election the result is not significant for all parties.

To summarize, in line with the findings in previous literature I reject the hypothesis that the voting behavior of people with different employment status is similar even when controlling for corruption in the model, in favor of an alternative that voting behavior differs for people with different employment status. The party of power "United Russia" in the 2003 election is likely to be opposed by privately employed workers, but is supported by the unemployed and those out of the labor force. A somewhat surprising result is that the privately employed oppose "United Russia" 
and the main supporters of the party of power "United Russia" are people who are out of the labor force. This is in contrast with the findings in the literature that the privately employed are likely to support the pro-reform party (Rodrik, 1995; Fidrmuc, 1998; Jackson et al., 2003). However, it should be pointed out that in previous literature corruption has not been taken into account during the analysis of the voting behavior of privately employed. If corruption is associated with the activity of the current Parliament (the party of power "United Russia"), it can be the case that the privately employed oppose it during elections.

\subsection{Corruption, Employment Status and Voting Results}

In this section I present how corruption across regions influences the voting behavior of people with different employment status in Russia. I find that corruption is likely to affect the voting behavior of all the groups of workers (see the interaction terms corruption_measure*employment_status in Tables 6-9).

In the previous section it was described that in the presence of corruption the unemployed are likely to support "United Russia" and "against all" option in case when state capture is used. However, with the indirect effect of corruption (the sign of the coefficient at the interaction term StateCapture $*$ Unemployed in Table 6) the unemployed are likely to oppose "United Russia" and "against all" option (though the coefficients are not significant), and support the Communist Party and "Rodina". When integral CPI is used, the sign is also opposite: because of the indirect effect of corruption the unemployed are likely to support more the Liberal Democratic Party, and oppose (previously supported) the "Union of Right Forces" in the 2003 election. The result also holds for the 1999 election: if the unemployed support some parties in the presence of corruption, because of the indirect effect of corruption they are likely to oppose these parties. This result is significant for almost all parties (except for "Yedinstvo", the Communist Party, and "Otechestvo").

For the state and privately employed in all specifications I also find a similar 
picture: if the main coefficient on variables state employed or privately employed is positive (i. e. state or privately employed support some parties), then because of the indirect effect they are likely to oppose these parties, and vice versa. For those who are out of the labor force this result holds only when state capture is used for the analysis of the 2003 election; for all other specifications there is not much significant evidence.

To summarize, I reject the hypothesis that corruption does not influence the voting behavior of all groups of workers, though the result is not robust for those who are out of the labor force. Thus, I find that corruption across regions influences the voting behavior of people with different employment status, although in the same way: for most groups of workers I find that because of corruption they are likely to support less the party which they have supported and support more the party which they have previously opposed. This is an expected result since I also find that regional differences in corruption in general negatively influence the voting result. This result is also in line with previous research. As mentioned above, Rundquist, Strom and Peters (1977) claim that this outcome is possible: when voters know that a candidate is corrupt, corruption may reduce support for this candidate and more vote for the opposite candidate.

\subsection{Participation in Elections}

To complete the analysis of voting results, I also study participation in elections since what drives people to participate in elections may also affect their decision to vote for a particular party. Results of the analysis of participation in the 1999 and 2003 elections are presented in Table 10.

The hypothesis that regional differences in corruption have no direct impact on voting participation is rejected when state capture is used (though for the 2003 elections only). Increase in state capture positively influences participation in election: this result is intuitive since if corruption is increasing, non-ignorant voters are likely 
to think that they can change the situation by voting. This finding is also in line with the result that with an increase in corruption people are less likely to vote against all parties described above: with an increase in corruption people prefer to vote for some party instead of voting against all parties.

When integral CPI is used for the analysis of the 2003 election, I do not find enough statistical evidence to reject the hypothesis that corruption has no effect on participation in elections.

Regional differences in corruption also may have an indirect effect on people's decision to participate: I reject the hypothesis of no indirect effect for the unemployed when state capture is used, for the privately employed in the 2003 election when integral CPI is used.

\subsection{Evaluation of Hard and Perceived Measures of Corrup- tion}

Since two different measures of corruption are used in the analysis, I provide an evaluation of perceived and hard evidence about regional differences in corruption.

I use state capture index as the hard measure of corruption. However, state capture, by definition, does not necessarily mean illegal activity. Slinko et al. (2005) define state capture as legal privileges given by the regional government to the largest firms in a region, which take various forms of soft budget constraints and which give political power to these firms. To use state capture as the corruption measure, I assume that firms with high political power are likely to seek the reelection of the current government to maintain received preferential treatment and could, therefore, influence the voting choice of their workers. While preferential treatments themselves are the legal activity of government, the use of firms' support which is based on the prospect of receiving preferential treatment for a party's reelection and private gains could be illegal. Another measure used in this paper, corruption perception index, is a widely used measure of corruption. It is based on the subjective responses 
of individuals and firms about various indicators of corruption. Both individuals and entrepreneurs are asked about various indicators of corruption (perceptions of everyday corruption, perceptions about amounts and frequency of bribes in individual and business sphere, etc.).

In the analysis hard and perceived measures of corruption are positively correlated with each other, though the correlation is not very high (about 18\%). However, in the analysis of voting results both corruption measures suggest similar results: a negative impact of corruption on voting results in general and evidence that corruption has an indirect effect on the voting behavior of people with different employment status, as described above. In the analysis of participation in elections, state capture explains better the direct effect of corruption on participation in elections, though the signs of the effects are similar for both measures. The magnitude of correlation of corruption and participation in elections is also higher when state capture is used. On the other hand, the corruption perception index has more explanatory power in the analysis of participation in elections for different groups of workers.

Since both measures are not strongly correlated with each other, I may assume no perfect collinearity and include both state capture and integral corruption perception index together into the analysis of voting results (see Table 8). The signs of the coefficients of two measures coincide for the Communist Party, Liberal Democratic Party, "Rodina", "Yabloko", and "against all" option, though the effect of state capture on voting results becomes insignificant for most of the parties.

Thus, the findings suggest that in the analysis of voting results both measures produce somewhat similar results. In the analysis of participation in elections the two measures have different explanatory power in explaining different effects, though the signs of the effect generally do not differ for the two measures. Olken's (2009) argument that corruption perceptions are subject to individual-level biases and do not always help to investigate the determinants of corruption correctly likely does not hold in the analysis of effects of corruption, though using different measures is 
likely to help investigate the effects better.

\subsection{Artificial Voting Results}

As the concluding step in the analysis of the effect of corruption on elections, I perform Monte Carlo simulations of voting results using the methodology and software CLARIFY developed by King et al. (2000) and Tomz et al. (2001, 2002). I generate predicted voting shares for each party using different values of corruption: average, maximal, and minimal. The results are summarized in Tables 11-15.

In comparison with the actual outcome of voting, different values of regional corruption suggest changes in the distribution of votes in the 1999 and 2003 elections. In 2003 with higher corruption (state capture) fewer parties would be elected to Parliament (received more than $5 \%$ of votes) with the Comminist and Liberal Democratic Parties receiving more votes than the actual outcome. With lower corruption (state capture) in 2003 more parties would be elected to the Parliament. When integral CPI is used, the results are similar: higher corruption would result in lower number of parties elected to the Parliament, and lower corruption would allow to elect more parties. In the artificial voting outcomes of the 1999 election, the party "Otechestvo" receives an unexpectedly high vote share in comparison with the actual outcomes and the confidence interval for the vote share of this party is broad, thus, the effects of different levels of regional corruption on voting results in this case are more uncertain than in the 2003 election.

\subsection{Sensitivity Analysis}

To ensure that the model's specification is correct, a series of specification tests are conducted: logs vs levels specification, tests for the presence of nonlinearities and omitted variable problem. As the results indicate, the chosen model is correctly specified and has no omitted variable problem. ${ }^{12}$

\footnotetext{
${ }^{12}$ Results of the specification tests are available upon request.
} 
To check the sensitivity of results obtained in the paper, I group the parties into four categoties, namely "the party of power", "anti-reform", "pro-reform", "protest voting", and estimate the model for the 1999 and 2003 elections. In 1999, "the party of power" includes "Yedinstvo" and "Otechestvo"; "anti-reform", or conservative, stands for the Communist Party; "pro-reform" includes the "Union of Right Forces" and "Yabloko"; and "protest voting" sums the shares of LDPR and "against all". In 2003, "the party of power" is "United Russia"; "anti-reform" and "pro-reform" groups include the same parties as in 1999; and "protest voting" group includes LDPR, "Rodina", and "against all". Such a classification is based on a modification of Titkov's (2004) grouping and potentially corresponds to the realities of the Russian political arena.

Results of the sensitivity checks are presented in Tables 6a-9a in the Appendix. The effects of corruption on voting shares of particular groups and on the voting behavior of people with different employment status remain somewhat similar to previous findings in the paper. The lower significance of some coefficients may be explained by the aggregation of dependent variables.

\section{Conclusion}

While investigating different aspects of political support for economic reforms in different transition countries, very few studies were concerned about economic voting in Russia. This paper develops an econometric model and estimates it using data from the Russian parliamentary elections in 1999 and 2003 in order to determine whether employment status indeed matters when accounting for regional corruption and whether the voting behavior of people with different employment status depends on the level of regional corruption. The paper analyses corruption's influence on the voting behavior of people with different employment status by division into four groups: privately and state employed, the unemployed, and those who are out of the labor force. Among the contributions of the paper is a combined approach which 
includes not only the analysis of voting results but also the analysis of participation in elections, the evaluation of hard and perceived measures of corruption, and simulations of artificial outcomes of elections using different values of corruption.

In line with previous research I find that people with different employment status are likely to vote differently, even when controlling for corruption. I also find that corruption negatively influences the voting results of all parties and positively influences participation in elections. Regional differences in corruption are likely to have indirect effects on people's decision to participate in elections and on the voting behavior of people with different employment status: because of corruption they are likely to support less those parties which they previously supported. Using two different measures of corruption produces similar results. Artificial vote shares generated by simulations suggest that the distribution of votes changes when different values of corruption are used. 


\section{References}

[1] Austin, A., Kosyaeva, T., Wilcox, N.(2005). Believe but Verify? Russian Views and the Market, CERGE-EI Working Paper \#278.

[2] Bardhan, P. (1997). Corruption and Development: A Review of Issues. The Journal of Economic Literature, 35(3), 1320-1346.

[3] Basu, S., Li, D. (1998). Corruption in Transition, William Davidson Institute Working Paper \#161.

[4] Blanchard, O. (1997). The Economics of Post-Communist Transition. New York: Oxford University Press.

[5] The Constitution of the Russian Federation. Adopted at National Voting on December 12, 1993.

[6] Dininio, P., Orttung, R. (2005). Explaining Patterns of Corruption in the Russian Regions. World Politics, 57(4), 500-529.

[7] Feddersen, T., Sandroni, A. (2006). A Theory of Participation in Elections. The American Economic Review, 96(4), 1271-1282.

[8] Fidrmuc, J. (1998). Political Sustainability of Economic Reforms: Dynamics and Analysis of Regional Economic Factors. The Journal of Policy Reform, 3, 139-156.

[9] Fidrmuc, J. (2000a). Political Support for Reforms: Economics of Voting in Transition Countries. The European Economic Review, 44, 1491-1513.

[10] Fidrmuc, J. (2000b). Economics of Voting in Post-Communist Countries. Electoral Studies, 19, 197-217.

[11] Fidrmuc, J. (2003). Economic Reform, Democracy and Growth During PostCommunist Transition. The European Journal of Political Economy, 19, 583604 .

[12] Frye, T. (2006). Ownership, Voting, and Job Creation in Russia. The European Journal of Political Economy, 22, 452-471.

[13] Grafstein, R. (2005). The Impact of Employment Status on Voting Behavior. The Journal of Politics, 67(3), 804-824.

[14] Greene, W. (2003). Econometric Analysis. Prentice Hall International, 5th edition.

[15] Hellman, J., Jones, G., Kaufmann, D. (2003). Seize the State, Seize the Day: State Capture, Corruption and Influence in Transition. The Journal of Comparative Economics, 31, 751-773.

[16] Hellman, J., Jones, G., Kaufmann, D., Schankerman, M. (2000). Measuring Governance, Corruption, and State Capture: How Firms and Bureaucrats Shape the Business Environment in Transition Economies, World Bank Policy Research Working Paper \#2312.

[17] Honacker, J., Katz, J., King, G. (2002). A Practical Statistical Model for Multiparty Electoral Data. Political Analysis, 10, 84-100. 
[18] Jackson, J. (2002). A Seemingly Unrelated Regression Model for Analyzing Multiparty Electons. Political Analysis, 10, 49-65.

[19] Jackson, J. (2003). A Computational Political Economy Model of Transition. In Political Economy of Transition and Development: Institutions, Politics, and Policies, Fidrmuc, J., Campos, N. (eds.), Kluwer Academic Publishers.

[20] Jackson, J., Klich, J., Poznańska, K. (2003). Economic Transition and Elections in Poland. The Economics of Transition, 11, 41-66.

[21] Katz, J., King, G. (1999). A Statistical Model for Multiparty Electoral Data. The American Political Science Review, 93, 15-32.

[22] King, G. (1990). Electoral Responsiveness and Partisan Bias in Multiparty Democracies. Legislative Studies Quarterly, 2, 159-181.

[23] King, G., Tomz, M., Wittenberg, J. (2000). Making the Most of Statistical Analyses: Improving Interpretation and Presentation. The American Journal of Political Science, 44(2), 347-361.

[24] Laffont, J., Tirole, J. (1991). The Politics of Government Decision-Making: A Theory of Regulatory Capture. The Quarterly Journal of Economics, 106, 1089-1127.

[25] Leijonhufvud, A., Ruhl, C. (1997). Russian Dilemmas. The American Economic Review, 87(2), 344-348.

[26] Mauro, P. (1995). Corruption and Growth. The Quarterly Journal of Economics, 110(3), 681-712.

[27] Olken, B. (2009). Corruption Perceptions vs Corruption Reality. The Journal of Public Economics, 93, 950-964.

[28] On the Changes in Laws of the Russian Federation in the Part of Cancelling the Form of Voting against All Candidates (Against All Lists of Candidates) [O Vnesenii Izmenenii v Otdelnye Zakonodatelnye Akty Rossiiskoi Federacii $v$ Chasti Otmeny Formy Golosovaniya protiv Vseh Kandidatov (protiv Vseh Spiskov Kandidatov)], Federal Law of the Russian Federation No. 107-FZ of July 12, 2006.

[29] On the Election of Deputies of the State Duma of the Federal Assembly of the Russian Federation [O Vnesenii Izmenenii v Otdelnye Zakonodatelnye Akty Rossiiskoi Federacii v Chasti Otmeny Formy Golosovaniya protiv Vseh Kandidatov (protiv Vseh Spiskov Kandidatov)], Federal Law of the Russian Federation No.175-FZ of December 20, 2002.

[30] On the Main Guarantees of Electoral Rights and the Right to Particiate in Referendum [Ob Osnovnyh Garantiyah Izbiratelnyh Prav i Prava na Uchastie v Referendume], Federal Law of the Russian Federation No. 67-FZ of June 12, 2002.

[31] Oversloot, H., van Holsteyn, J., van der Berg, G. (2002). Against All: Exploring the Vote 'Against All' in the Russian Federation's Electoral System. The Journal of Communist Studies and Transition Politics, 18, 31-50. 
[32] Persson, T., Tabellini, G., Trebbi, F. (2003). Electoral Rules and Corruption. The Journal of the European Economic Association, 1(4), 958-989.

[33] Peters, J., Welch, S. (1980). The Effects of Charges of Corruption on Voting Behavior in Congressional Elections. The American Political Science Review, 74(3), 697-708.

[34] Rodrik, D. (1995). The Dynamics of Political Support for Reforms in Economies in Transition. The Journal of Japanese and International Economics, 9, 403425.

[35] Rose-Ackerman, S. (1999). Corruption and Government: Causes, Consequences, and Reform. Cambridge University Press, Cambridge, New York and Melbourne.

[36] Rundquist, B., Strom, G., Peters, J. (1977). Corrupt Politicians and Their Electoral Support: Some Experimental Observations. The American Political Science Review, 71(3), 954-963.

[37] Safavian, M., Graham, D., Gonzalez-Vega, C. (2001). Corruption and Microenterprises in Russia. World Development, 29(7), 1215-1224.

[38] Shleifer, A., Vishny, R. (1993). Corruption. The Quarterly Journal of Economics, 108(3), 599-617.

[39] Slinko, I., Yakovlev, E., Zhuravskaya, E. (2005). Laws for Sale: Evidence from Russia. The American Law and Economics Review, 7(1), 284-318.

[40] Stiglitz, J. (1999). Whither Reform? Ten Years of the Transition. Keynote Address to the World Bank Conference on Development Economics, 28-30 April 1999, Washington.

[41] Svensson, J. (2005). Eight Questions about Corruption. The Journal of Economic Perspectives, 19(3), 19-42.

[42] Tavares, S. (2007). Do Rapid Political and Trade Liberalizations Increase Corruption? The European Journal of Political Economy, 23, 1053-1076.

[43] Titkov, A. (2004). Russia during 2000s: New Political System, New Political Geography [Rossiya 2000h Godov: Novaya Politicheskaya Sistema, Novaya Politicheskaya Geografiya]. Proc. of Intl. Symphosium "Ways for Russia: Existing Constraints and Possible Alternatives" [Puti Rossii: Sushestvuyushie Ogranicheniya i Vozmozhnye Varianty], Moscow, Jan 15-17, 107-115.

[44] Tomz, M., Tucker, J., Wittenberg, J. (2002). A Convenient Statistical Model for Multiparty Electoral Data. Political Analysis, 10, 66-83.

[45] Tomz, M., Wittenberg, J., and King, G. (2001). CLARIFY: Software for Interpreting and Presenting Statistical Results. Version 2.0 Cambridge, MA: Harvard University, June 1. http://gking.harvard.edu

[46] Transparency International and INDEM Foundation (2002). Corruption Indices for Russian Regions. Available online at http://www.transparency.org.ru/proj_index.asp.

[47] Warner, A. (2001). Is Economic Reform Popular at the Polls? Russia 1995. The Journal of Comparative Economiç, 29, 448-465. 
[48] Welch, S., Hibbing, J. (1997). The Effects of Charges of Corruption on Voting Behavior in Congressional Elections, 1982-1990. The Journal of Politics, 59(1), 226-239.

[49] Wooldridge, J. (2002). Econometric Analysis of Cross Section and Panel Data. Cambridge, MA.: MIT Press.

[50] Yakovlev, E., Zhuravskaya, E. (2009). State Capture: From Yeltsin to Putin. In Corruption, Development and Institutional Design. J. Kornai, L. Matyas and G. Roland (eds.), New York NY: Palgrave Macmillan.

[51] Zellner, A. (1962). An Efficient Method of Estimating Seemingly Unrelated Regressions and Tests of Aggregation Bias. The Journal of the American Statistical Association, 57, 500-509. 


\section{Appendix}

\section{Main Tables}

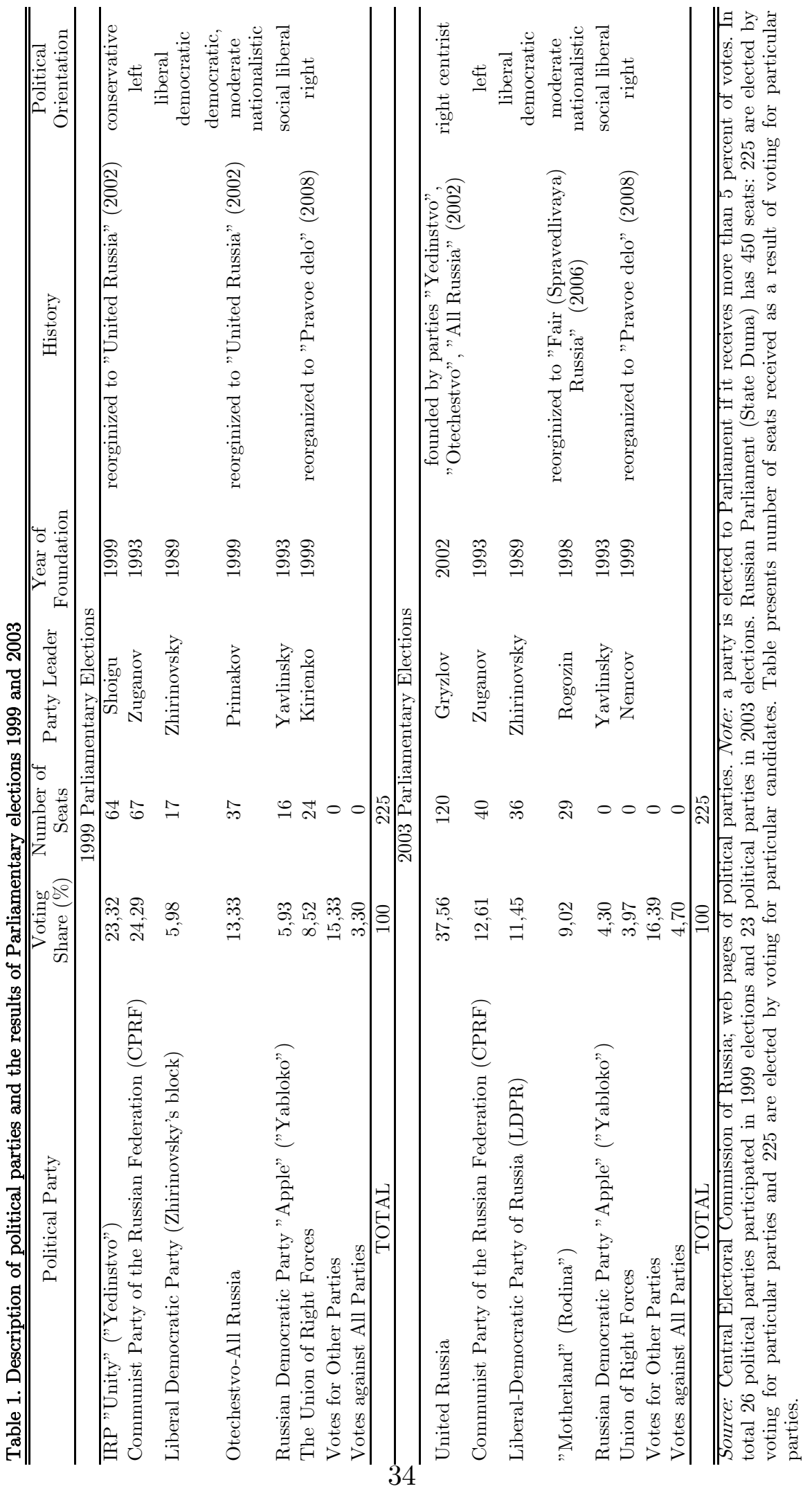


Table 2. Data Description (before transformation, year 2003)

\begin{tabular}{|c|c|c|c|c|c|}
\hline$\overline{\text { Variable }}$ & Obs & Mean & Std. Dev. & $\overline{M i n}$ & $\overline{\operatorname{Max}}$ \\
\hline \multicolumn{6}{|c|}{ Corruption variables } \\
\hline State capture & 215 & 0,333 & 0,174 & 0,200 & 1 \\
\hline Integral CPI & 164 & 0,591 & 0,220 & 0 & 1 \\
\hline \multicolumn{6}{|c|}{ Other explanatory variables } \\
\hline Unemployed (thous. people) & 224 & 26,553 & 14,229 & 0,500 & 79,100 \\
\hline State employed (thous. people) & 224 & 106,845 & 33,092 & 7,900 & 250,700 \\
\hline Privately employed (thous. people) & 224 & 147,078 & 43,184 & 2,700 & 258,700 \\
\hline Out of the labor force (thous. people) & 224 & 26,233 & 7,360 & 0,388 & 43,829 \\
\hline Real GRP per capita (thous. rubles) & 214 & 63,498 & 47,699 & 8,844 & 307,774 \\
\hline Students (thous. people) & 221 & 29,115 & 16,571 & 0,000 & 85,300 \\
\hline Pensioners (thous. people) & 224 & 169,429 & 44,557 & 4,000 & 281,000 \\
\hline Registered voters (thous. people) & 225 & 484,028 & 123,902 & 13,258 & 777,959 \\
\hline Urban population ( $\%$ of population in region) & 223 & 0,729 & 0,151 & 0,237 & 1 \\
\hline Moscow & 225 & 0,067 & 0,250 & 0 & 1 \\
\hline \multicolumn{6}{|c|}{ Voting results } \\
\hline United Russia (thous. people voted) & 225 & 101,232 & 56,614 & 3,514 & 420,186 \\
\hline Communist Party (thous. people voted) & 225 & 33,990 & 15,657 & 0,323 & 90,570 \\
\hline Liberal Democratic Party (thous. people voted) & 225 & 31,026 & 13,326 & 0,705 & 84,588 \\
\hline "Motherland" (Rodina") (thous. people voted) & 225 & 24,378 & 12,256 & 0,545 & 76,809 \\
\hline "Apple" ("Yabloko") (thous. people voted) & 225 & 11,647 & 7,244 & 0,138 & 39,111 \\
\hline Union of Right Forces (thous. people voted) & 225 & 10,726 & 7,846 & 0,207 & 50,543 \\
\hline Against All (thous. people voted) & 225 & 12,674 & 5,362 & 0,332 & 25,869 \\
\hline Other parties (thous. people voted) & 225 & 39,886 & 15,749 & 0,875 & 87,130 \\
\hline Number of voters participated (thous. people) & 225 & 265,265 & 82,593 & 6,640 & 532,659 \\
\hline
\end{tabular}

Source: Russian State Statistical Office; Central Electoral Commission of Russia; author's calculations. Notes . Voting district used as an unit of observation. During the 2003 parliamentary elections there were 225 votng districts in total. Observations for the unemployed, state employed, privately employed, out of the labor force, real GRP per capita, number of students, number of pensioners are missed for the Chechen Republic. Observations for real GRP per capita, number of students are missed for those voting districts that correspond to national districts within larger Russian regions.

Table 3. Data Description (after transformation, year 2003)

\begin{tabular}{|c|c|c|c|c|c|}
\hline Variable & Obs & Mean & Std. Dev. & Min & Max \\
\hline \multicolumn{6}{|c|}{ Dependent variables $(\mathrm{y})$} \\
\hline United Russia & 225 & 0,911 & 0,445 & -0.439 & 3,084 \\
\hline Communist Party of the Russian Federation (CPRF) & 225 & -0.220 & 0,487 & $-3,476$ & 1,696 \\
\hline Liberal Democratic Party of Russia (LDPR) & 225 & -0.303 & 0,476 & $-3,430$ & 0,583 \\
\hline "Motherland" (Rodina") & 225 & -0.587 & 0,642 & $-4,038$ & 1,044 \\
\hline "Apple" ("Yabloko") & 225 & -1.331 & 0,780 & $-2,901$ & 4,600 \\
\hline Union of Right Forces & 225 & -1.498 & 0,750 & $-3,223$ & 0,332 \\
\hline Votes against All Parties & 225 & -1.188 & 0,505 & $-3,535$ & $-0,004$ \\
\hline \multicolumn{6}{|c|}{ Exlanatory variables } \\
\hline 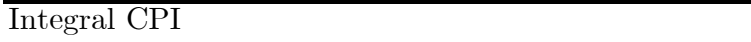 & 164 & 0,409 & 0,220 & 0 & 1 \\
\hline Ln(Number Participated) & 225 & 5,489 & 0,555 & 1,893 & 6,278 \\
\hline Ln(Unemployed) & 224 & 3,070 & 0,771 & $-0,693$ & 4,371 \\
\hline Ln(State Employed) & 224 & 4,597 & 0,465 & 2,067 & 5,524 \\
\hline Ln(Privately Employed) & 224 & 4,892 & 0,596 & 0,993 & 5,556 \\
\hline $\operatorname{Ln}($ Out of the Labor Force) & 224 & 3,172 & 0,633 & $-0,947$ & 3,780 \\
\hline Ln(Real GRP per capita) & 214 & 3,979 & 0,539 & 2,180 & 5,729 \\
\hline Ln(Number of Students) & 220 & 3,183 & 0,787 & $-2,303$ & 4,446 \\
\hline Ln(Number of Pensioners) & 224 & 5,046 & 0,564 & 1,386 & 5,638 \\
\hline Ln(Number of Registered Voters) & 225 & 6,100 & 0,549 & 2,585 & 6,657 \\
\hline
\end{tabular}

Source: author's calculations. Notes. Voting district used as an unit of observation. During the 2003 parliamentary elections there were 225 votng districts in total. Observations for Ln (unemployed), Ln (state employed), Ln(privately employed), $\ln$ (out of labor force), Ln(real GRP per capita), Ln(number of students), Ln(number of pensioners) are missed for the Chechen Republic. Observations for Ln(real GRP per capita), $\operatorname{Ln}$ (number of students) are missed for those voting districts that correspond to national districts within larger Russian regions. 
Table 4. Data Description (before transformation, year 1999)

\begin{tabular}{|c|c|c|c|c|c|}
\hline Variable & Obs & Mean & Std. Dev. & Min & Max \\
\hline \multicolumn{6}{|c|}{ Corruption variables } \\
\hline State Capture & 215 & 0,361 & 0,212 & 0,200 & 1 \\
\hline \multicolumn{6}{|c|}{ Other explanatory variables } \\
\hline Unemployed (thous. people) & 224 & 41,620 & 17,339 & 0,700 & 120,350 \\
\hline State employed (thous. people) & 224 & 108,777 & 32,648 & 7,400 & 245,600 \\
\hline Privately employed (thous. people) & 224 & 133,163 & 40,625 & 1,800 & 236,900 \\
\hline Out of the labor force (thous. people) & 224 & 27,138 & 17,985 & 0,579 & 274,829 \\
\hline Real GRP per capita (thous. rubles) & 214 & 20,209 & 14,347 & 3,371 & 78,096 \\
\hline Students (thous. people) & 216 & 18,856 & 11,008 & 0,500 & 60,700 \\
\hline Pensioners (thous. people) & 224 & 170,799 & 46,436 & 4,000 & 290,000 \\
\hline Registered voters (thous. people) & 224 & 482,466 & 124,395 & 12,759 & 782,019 \\
\hline Urban population ( $\%$ of population in region) & 223 & 72,831 & 15,178 & 25,400 & 100,000 \\
\hline Moscow & 224 & 0,067 & 0,251 & 0 & 1 \\
\hline \multicolumn{6}{|c|}{ Voting results } \\
\hline IRP "Unity" ("Yedinstvo") (thous. people voted) & 224 & 69,414 & 33,559 & 0,855 & 172,167 \\
\hline Communist Party (thous. people voted) & 224 & 72,302 & 35,326 & 0,959 & 219,602 \\
\hline $\begin{array}{l}\text { Liberal-Democratic Party (Zhirinovsky's block) (thous. } \\
\text { people voted) }\end{array}$ & 224 & 17,723 & 8,199 & 0,424 & 48,063 \\
\hline Otechestvo-All Russia (thous. people voted) & 224 & 39,672 & 43,504 & 0,434 & 264,837 \\
\hline "Apple" ("Yabloko") (thous. people voted) & 224 & 17,663 & 10,487 & 0,357 & 59,477 \\
\hline Union of Right Forces (thous. people voted) & 224 & 25,344 & 14,464 & 0,309 & 75,824 \\
\hline Against All (thous. people voted) & 224 & 9,815 & 3,807 & 0,269 & 20,810 \\
\hline Other parties (thous. people voted) & 224 & 39,814 & 13,949 & 1,349 & 83,982 \\
\hline Number of voters participated (thous. people) & 224 & 291,833 & 82,547 & 7,704 & 512,256 \\
\hline
\end{tabular}

Source: Russian State Statistical Office; Central Electoral Commission of Russia; author's calculations. Notes. Voting district used as an unit of observation. During the 1999 parliamentary elections there were 224 votng districts in total. Observations for real GRP per capita, number of students, urban population are missed for those voting districts that correspond to national districts within larger Russian regions.

Table 5. Data Description (after transformation, year 1999)

\begin{tabular}{lccccc}
\multicolumn{1}{c}{ Variable } & Obs & Mean & Std. Dev. & Min & Max \\
\hline \hline & Dependent variables (y) & & & & \\
\hline IRP "Unity" ("Yedinstvo") & 224 & 0,493 & 0,530 & $-1,205$ & 2,778 \\
Communist Party of the Russian Federation (CPRF) & 224 & 0,515 & 0,538 & $-0,919$ & 3,021 \\
Liberal Democratic Party (Zhirinovsky's block) & 224 & $-0,863$ & 0,394 & $-3,154$ & 0,094 \\
Otechestvo-All Russia & 224 & 2,731 & 1,323 & $-1,677$ & 5,488 \\
Russian Democratic Party "Apple" ("Yabloko") & 224 & $-0,951$ & 0,589 & $-2,598$ & 0,377 \\
The Union of Right Forces & 224 & $-0,577$ & 0,534 & $-2,399$ & 0,708 \\
Votes against All Parties & 224 & $-1,427$ & 0,333 & $-2,736$ & $-0,466$ \\
\hline & Exlanatory variables & & & & \\
\hline Ln(Number Participated) & 224 & 5,589 & 0,550 & 2,042 & 6,239 \\
Ln(Unemployed) & 224 & 3,605 & 0,610 & $-0,357$ & 4,790 \\
Ln(State Employed) & 224 & 4,616 & 0,464 & 2,001 & 5,504 \\
Ln(Privately Employed) & 224 & 4,781 & 0,645 & 0,588 & 5,468 \\
Ln(Out of the Labor Force) & 224 & 3,187 & 0,576 & -0.546 & 5,616 \\
Ln(Real GRP per capita) & 214 & 2,838 & 0,546 & 1,215 & 4,358 \\
Ln(Number of Students) & 216 & 2,762 & 0,671 & $-0,693$ & 4,106 \\
Ln(Number of Pensioners) & 224 & 5,052 & 0,567 & 1,386 & 5,670 \\
Ln(Number of Registered Voters) & 224 & 6,095 & 0,554 & 2,546 & 6,662 \\
\hline \hline
\end{tabular}

Source: author's calculations. Notes. Voting district used as an unit of observation. During the 1999 parliamentary elections there were 224 votng districts in total. Observations for Ln(real GRP per capita) and $\operatorname{Ln}$ (number of students) are missed for those voting districts that correspond to national districts within larger Russian regions. 
Table 6. SUR Estimation of the 2003 Voting Results (State Capture Index is Used to Control for Corruption)

\begin{tabular}{|c|c|c|c|c|c|c|c|}
\hline & $\begin{array}{l}\text { United } \\
\text { Russia }\end{array}$ & $\begin{array}{l}\text { Communist } \\
\text { Party }\end{array}$ & $\begin{array}{c}\text { Liberal } \\
\text { Democratic } \\
\text { Party }\end{array}$ & $\begin{array}{c}\text { NPU } \\
\text { "Motherland" } \\
\text { ("Rodina") }\end{array}$ & $\begin{array}{l}\text { RDP "Apple" } \\
\text { ("Yabloko") }\end{array}$ & $\begin{array}{l}\text { Union of } \\
\text { Right } \\
\text { Forces }\end{array}$ & Against All \\
\hline & $(1)$ & $(2)$ & $(3)$ & $(4)$ & $(5)$ & $(6)$ & $(7)$ \\
\hline State Capture & $\begin{array}{l}-11.978 \\
(8.363)\end{array}$ & $\begin{array}{l}10.293 \\
(7.643)\end{array}$ & $\begin{array}{c}17.545^{* *} \\
(7.764)\end{array}$ & $\begin{array}{l}1.435 \\
(9.723)\end{array}$ & $\begin{array}{c}-2.347 \\
(13.722)\end{array}$ & $\begin{array}{c}-27.843^{* *} \\
(12.866)\end{array}$ & $\begin{array}{c}-0.412 \\
(8.317))\end{array}$ \\
\hline Ln(Unemployed) & $\begin{array}{l}0.593^{*} \\
(0.307)\end{array}$ & $\begin{array}{l}-0.211 \\
(0.280)\end{array}$ & $\begin{array}{l}0.376 \\
(0.285)\end{array}$ & $\begin{array}{l}-0.486 \\
(0.357)\end{array}$ & $\begin{array}{l}-0.206 \\
(0.503)\end{array}$ & $\begin{array}{c}0.053 \\
(0.472)\end{array}$ & $\begin{array}{l}0.563^{*} \\
(0.305)\end{array}$ \\
\hline Ln(State Employed) & $\begin{array}{l}-0.415 \\
(0.627)\end{array}$ & $\begin{array}{c}0.021 \\
(0.573)\end{array}$ & $\begin{array}{l}-0.415 \\
(0.582)\end{array}$ & $\begin{array}{l}-1.244^{*} \\
(0.729)\end{array}$ & $\begin{array}{l}-0.567 \\
(1.029)\end{array}$ & $\begin{array}{l}-0.821 \\
(0.829)\end{array}$ & $\begin{array}{c}-1.400^{* *} \\
(0.624)\end{array}$ \\
\hline Ln(Privately Employed) & $\begin{array}{c}-2.057^{* * *} \\
(0.662)\end{array}$ & $\begin{array}{c}0.561 \\
(0.605)\end{array}$ & $\begin{array}{c}1.931^{* * *} \\
(0.615)\end{array}$ & $\begin{array}{l}-0.198 \\
(0.770)\end{array}$ & $\begin{array}{c}0.519 \\
(1.086)\end{array}$ & $\begin{array}{l}-1.500 \\
(1.018)\end{array}$ & $\begin{array}{l}-0.147 \\
(0.658)\end{array}$ \\
\hline $\operatorname{Ln}$ (Out of the Labor Force) & $\begin{array}{c}3.578^{* * *} \\
(0.664)\end{array}$ & $\begin{array}{c}0.877 \\
(0.607)\end{array}$ & $\begin{array}{c}-2.705^{* * *} \\
(0.616)\end{array}$ & $\begin{array}{l}-0.620 \\
(0.772)\end{array}$ & $\begin{array}{c}0.671 \\
(1.089)\end{array}$ & $\begin{array}{c}2.951^{* * *} \\
(1.021)\end{array}$ & $\begin{array}{c}-1.318^{* *} \\
(0.660)\end{array}$ \\
\hline $\begin{array}{l}\text { State Capture* } \\
\text { Ln(Unemployed) }\end{array}$ & $\begin{array}{l}-1.414 \\
(1.051)\end{array}$ & $\begin{array}{l}1.623^{*} \\
(0.960)\end{array}$ & $\begin{array}{c}0.486 \\
(0.975)\end{array}$ & $\begin{array}{c}2.799^{* *} \\
(1.222)\end{array}$ & $\begin{array}{c}2.054 \\
(1.724)\end{array}$ & $\begin{array}{l}-0.791 \\
(1.616)\end{array}$ & $\begin{array}{l}-0.798 \\
(1.045)\end{array}$ \\
\hline $\begin{array}{l}\text { State Capture* } \\
\text { Ln(State Employed) }\end{array}$ & $\begin{array}{l}2.071 \\
(2.240)\end{array}$ & $\begin{array}{l}-2.387 \\
(2.047)\end{array}$ & $\begin{array}{l}-1.088 \\
(2.080)\end{array}$ & $\begin{array}{l}-1.825 \\
(2.604)\end{array}$ & $\begin{array}{c}0.000 \\
(3.675)\end{array}$ & $\begin{array}{c}4.670 \\
(3.446)\end{array}$ & $\begin{array}{l}1.315 \\
(2.227)\end{array}$ \\
\hline $\begin{array}{l}\text { State Capture* } \\
\text { Ln(Privately Employed) }\end{array}$ & $\begin{array}{c}4.464^{* *} \\
(2.038)\end{array}$ & $\begin{array}{l}-0.797 \\
(1.862)\end{array}$ & $\begin{array}{c}-5.683^{* * *} \\
(1.892)\end{array}$ & $\begin{array}{l}-0.427 \\
(2.369)\end{array}$ & $\begin{array}{l}-0.803 \\
(3.343)\end{array}$ & $\begin{array}{l}5.719^{*} \\
(3.135)\end{array}$ & $\begin{array}{l}-1.201 \\
(2.026)\end{array}$ \\
\hline $\begin{array}{l}\text { State Capture* } \\
\text { Ln(Out of the Labor Force) }\end{array}$ & $\begin{array}{l}-4.778^{* * *} \\
(1.719)\end{array}$ & $\begin{array}{l}-0.072 \\
(1.571)\end{array}$ & $\begin{array}{c}4.647^{* * *} \\
(1.596)\end{array}$ & $\begin{array}{l}-0.337 \\
(1.998)\end{array}$ & $\begin{array}{l}-0.330 \\
(2.820)\end{array}$ & $\begin{array}{c}-6.607^{* *} \\
(2.644)\end{array}$ & $\begin{array}{c}0.864 \\
(1.709)\end{array}$ \\
\hline Ln (Real GRP per capita) & $\begin{array}{l}-0.079 \\
(0.112)\end{array}$ & $\begin{array}{l}-0.122 \\
(0.102)\end{array}$ & $\begin{array}{c}0.302^{* * *} \\
(0.104)\end{array}$ & $\begin{array}{c}0.395^{* * *} \\
(0.130)\end{array}$ & $\begin{array}{c}0.106 \\
(0.183)\end{array}$ & $\begin{array}{l}-0.152 \\
(0.172)\end{array}$ & $\begin{array}{c}0.310^{* * *} \\
(0.111)\end{array}$ \\
\hline Ln (Students) & $\begin{array}{l}-0.075 \\
(0.122)\end{array}$ & $\begin{array}{l}-0.048 \\
(0.112)\end{array}$ & $\begin{array}{l}-0.178 \\
(0.114)\end{array}$ & $\begin{array}{l}-0.215 \\
(0.142)\end{array}$ & $\begin{array}{c}-0.419^{* *} \\
(0.201)\end{array}$ & $\begin{array}{l}-0.139 \\
(0.188)\end{array}$ & $\begin{array}{l}-0.118 \\
(0.122)\end{array}$ \\
\hline Ln (Pensioners) & $\begin{array}{l}-0.523 \\
(0.402)\end{array}$ & $\begin{array}{c}-0.670^{*} \\
(0.367)\end{array}$ & $\begin{array}{c}0.762^{* *} \\
(0.373)\end{array}$ & $\begin{array}{c}0.050 \\
(0.467)\end{array}$ & $\begin{array}{c}-2.583^{* * *} \\
(0.659)\end{array}$ & $\begin{array}{c}-3.525^{* * *} \\
(0.618)\end{array}$ & $\begin{array}{c}0.459 \\
(0.399)\end{array}$ \\
\hline $\begin{array}{l}\text { Ln (Number of Registered } \\
\text { Voters) }\end{array}$ & $\begin{array}{c}-0.865^{* *} \\
(0.427)\end{array}$ & $\begin{array}{l}0.152 \\
(0.390)\end{array}$ & $\begin{array}{l}0.746^{*} \\
(0.396)\end{array}$ & $\begin{array}{c}2.629^{* * *} \\
(0.496)\end{array}$ & $\begin{array}{c}2.168^{* * *} \\
(0.701)\end{array}$ & $\begin{array}{c}2.279^{* * *} \\
(0.657)\end{array}$ & $\begin{array}{c}1.940^{* * *} \\
(0.425)\end{array}$ \\
\hline Share of Urban Population & $\begin{array}{c}1.384^{* * *} \\
(0.372)\end{array}$ & $\begin{array}{l}-0.487 \\
(0.340)\end{array}$ & $\begin{array}{c}0.093 \\
(0.345)\end{array}$ & $\begin{array}{c}0.717^{*} \\
(0.432)\end{array}$ & $\begin{array}{c}3.367 * * * \\
(0.610)\end{array}$ & $\begin{array}{c}2.763^{* * *} \\
(0.572)\end{array}$ & $\begin{array}{c}0.795^{* *} \\
(0.370)\end{array}$ \\
\hline Moscow & $\begin{array}{c}-0.619 \\
(0.637)\end{array}$ & $\begin{array}{c}1.168^{* *} \\
(0.582)\end{array}$ & $\begin{array}{l}0.992^{*} \\
(0.592)\end{array}$ & $\begin{array}{c}3.314^{* * *} \\
(0.741)\end{array}$ & $\begin{array}{c}2.340^{* *} \\
(1.045)\end{array}$ & $\begin{array}{c}0.047 \\
(0.980)\end{array}$ & $\begin{array}{l}1.036^{*} \\
(0.634)\end{array}$ \\
\hline Constant & $\begin{array}{c}7.113^{* * * *} \\
(2.727)\end{array}$ & $\begin{array}{l}-1.797 \\
(2.493)\end{array}$ & $\begin{array}{c}-9.821^{* * *} \\
(2.532)\end{array}$ & $\begin{array}{c}-7.771^{* *} \\
(3.171)\end{array}$ & $\begin{array}{l}-4.254 \\
(4.475)\end{array}$ & $\begin{array}{c}3.501 \\
(4.196)\end{array}$ & $\begin{array}{c}-7.259^{* * *} \\
(2.712)\end{array}$ \\
\hline Number of observations & 205 & 205 & 205 & 205 & 205 & 205 & 205 \\
\hline "R-squared" & 0,317 & 0,355 & 0,313 & 0,464 & 0,424 & 0,437 & 0,395 \\
\hline
\end{tabular}

Source: author's calculations. Notes. Voting district is used as an unit of observation. During the 2003 parliamentary elections there were 225 votng districts in total. The number of observations is reduced due to the absence of data on corruption. Columns present the results for a particular party. Explanatory variables are given in rows. Standard errors are in parentheses. $* * *$, and $* * *$ stand for $10 \%, 5 \%$, and $1 \%$ significance levels, respectively. The choice of SUR is justified since the Breusch-Pagan test for independent equations $\left(\mathrm{chi}^{2}(21)=584.431^{* * *}\right)$ rejects the null hypothesis of independence of residuals across the equations. 
Table 7. SUR Estimation of the 2003 Voting Results (Integral CPI is Used to Control for Corruption)

\begin{tabular}{|c|c|c|c|c|c|c|c|}
\hline & $\begin{array}{l}\text { United } \\
\text { Russia }\end{array}$ & $\begin{array}{l}\text { Communist } \\
\text { Party }\end{array}$ & $\begin{array}{c}\text { Liberal } \\
\text { Democratic } \\
\text { Party }\end{array}$ & $\begin{array}{c}\text { NPU } \\
\text { "Motherland" } \\
\text { ("Rodina") }\end{array}$ & $\begin{array}{c}\text { RDP "Apple" } \\
\text { ("Yabloko") }\end{array}$ & $\begin{array}{c}\text { Union of } \\
\text { Right } \\
\text { Forces } \\
\end{array}$ & Against All \\
\hline & (1) & $(2)$ & $(3)$ & $(4)$ & $(5)$ & $(6)$ & $(7)$ \\
\hline Integral CPI & $\begin{array}{l}-4.537 \\
(9.639)\end{array}$ & $\begin{array}{c}-19.631^{* *} \\
(9.230)\end{array}$ & $\begin{array}{l}-12.443 \\
(7.793)\end{array}$ & $\begin{array}{c}-39.635^{* * *} \\
(13.854)\end{array}$ & $\begin{array}{c}-7.902 \\
(21.018)\end{array}$ & $\begin{array}{c}-9.882 \\
(16.458)\end{array}$ & $\begin{array}{c}-21.932^{* *} \\
(9.672)\end{array}$ \\
\hline Ln(Unemployed) & $\begin{array}{l}-0.110 \\
(0.307)\end{array}$ & $\begin{array}{l}-0.003 \\
(0.294)\end{array}$ & $\begin{array}{l}-0.010 \\
(0.248)\end{array}$ & $\begin{array}{c}0.150 \\
(0.441)\end{array}$ & $\begin{array}{c}1.071 \\
(0.669)\end{array}$ & $\begin{array}{l}0.954^{*} \\
(0.524)\end{array}$ & $\begin{array}{l}-0.155 \\
(0.308)\end{array}$ \\
\hline Ln(State Employed) & $\begin{array}{l}-0.311 \\
(0.424)\end{array}$ & $\begin{array}{c}-1.053^{* * *} \\
(0.406)\end{array}$ & $\begin{array}{l}-0.098 \\
(0.343)\end{array}$ & $\begin{array}{c}-3.073^{* * *} \\
(0.609)\end{array}$ & $\begin{array}{l}-1.571^{*} \\
(0.925)\end{array}$ & $\begin{array}{l}-1.274^{*} \\
(0.724)\end{array}$ & $\begin{array}{c}-1.010^{* *} \\
(0.425)\end{array}$ \\
\hline Ln(Privately Employed) & $\begin{array}{l}-0.663 \\
(0.456)\end{array}$ & $\begin{array}{l}1.005^{* *} \\
(0.437)\end{array}$ & $\begin{array}{c}0.418 \\
(0.369)\end{array}$ & $\begin{array}{l}-1.123^{*} \\
(0.656)\end{array}$ & $\begin{array}{c}0.692 \\
(0.995)\end{array}$ & $\begin{array}{l}1.178 \\
(0.779)\end{array}$ & $\begin{array}{c}-1.071^{* *} \\
(0.458)\end{array}$ \\
\hline $\operatorname{Ln}$ (Out of the Labor Force) & $\begin{array}{r}2.495^{* *} \\
(1.008)\end{array}$ & $\begin{array}{l}-1.861^{*} \\
(0.965)\end{array}$ & $\begin{array}{l}-0.597 \\
(0.815)\end{array}$ & $\begin{array}{l}-1.655 \\
(1.449)\end{array}$ & $\begin{array}{l}0.418 \\
(2.198)\end{array}$ & $\begin{array}{c}-3.580^{* *} \\
(1.721)\end{array}$ & $\begin{array}{c}-0.838 \\
(1.011)\end{array}$ \\
\hline $\begin{array}{l}\text { Integral CPI* } \\
\text { Ln(Unemployed) }\end{array}$ & $\begin{array}{c}0.811 \\
(0.705)\end{array}$ & $\begin{array}{c}0.428 \\
(0.675)\end{array}$ & $\begin{array}{c}1.154^{* *} \\
(0.570)\end{array}$ & $\begin{array}{l}-0.364 \\
(1.014)\end{array}$ & $\begin{array}{l}-1.872 \\
(1.538)\end{array}$ & $\begin{array}{l}-2.121^{*} \\
(1.204)\end{array}$ & $\begin{array}{l}1.071 \\
(0.708)\end{array}$ \\
\hline $\begin{array}{l}\text { Integral CPI* } \\
\text { Ln(State Employed) }\end{array}$ & $\begin{array}{c}0.502 \\
(1.108)\end{array}$ & $\begin{array}{l}1.845^{*} \\
(1.061)\end{array}$ & $\begin{array}{c}0.758 \\
(0.896)\end{array}$ & $\begin{array}{c}5.369^{* * *} \\
(1.593)\end{array}$ & $\begin{array}{l}3.713 \\
(2.417)\end{array}$ & $\begin{array}{l}3.171^{*} \\
(1.892)\end{array}$ & $\begin{array}{l}1.623 \\
(1.112)\end{array}$ \\
\hline $\begin{array}{l}\text { Integral CPI* } \\
\text { Ln(Privately Employed) }\end{array}$ & $\begin{array}{c}0.435 \\
(0.921)\end{array}$ & $\begin{array}{l}-1.234 \\
(0.882)\end{array}$ & $\begin{array}{c}0.206 \\
(0.745)\end{array}$ & $\begin{array}{c}3.129^{* *} \\
(1.324)\end{array}$ & $\begin{array}{l}-0.896 \\
(2.009)\end{array}$ & $\begin{array}{l}-1.073 \\
(1.573)\end{array}$ & $\begin{array}{c}1.855^{* *} \\
(0.924)\end{array}$ \\
\hline $\begin{array}{l}\text { Integral CPI* } \\
\text { Ln(Out of the Labor Force) }\end{array}$ & $\begin{array}{l}-0.939 \\
(1.802)\end{array}$ & $\begin{array}{c}4.560^{* * *} \\
(1.726)\end{array}$ & $\begin{array}{l}1.098 \\
(1.457)\end{array}$ & $\begin{array}{l}-0.039 \\
(2.591)\end{array}$ & $\begin{array}{l}0.235 \\
(3.930)\end{array}$ & $\begin{array}{l}2.175 \\
(3.077)\end{array}$ & $\begin{array}{l}0.250 \\
(1.808)\end{array}$ \\
\hline Ln (Real GRP per capita) & $\begin{array}{c}0.364^{* * *} \\
(0.124)\end{array}$ & $\begin{array}{l}-0.038 \\
(0.118)\end{array}$ & $\begin{array}{l}-0.032 \\
(0.100)\end{array}$ & $\begin{array}{l}-0.218 \\
(0.178)\end{array}$ & $\begin{array}{l}-0.192 \\
(0.269)\end{array}$ & $\begin{array}{l}-0.197 \\
(0.211)\end{array}$ & $\begin{array}{c}0.080 \\
(0.124)\end{array}$ \\
\hline Ln (Number of Students) & $\begin{array}{l}-0.149^{*} \\
(0.092)\end{array}$ & $\begin{array}{l}0.157^{*} \\
(0.088)\end{array}$ & $\begin{array}{l}-0.109 \\
(0.075)\end{array}$ & $\begin{array}{c}0.004 \\
(0.133)\end{array}$ & $\begin{array}{c}-0.447^{* *} \\
(0.201)\end{array}$ & $\begin{array}{l}-0.163 \\
(0.158)\end{array}$ & $\begin{array}{c}0.041 \\
(0.093)\end{array}$ \\
\hline Ln (Number of Pensioners) & $\begin{array}{c}0.535 \\
(0.475)\end{array}$ & $\begin{array}{c}0.007 \\
(0.455)\end{array}$ & $\begin{array}{l}-0.158 \\
(0.384)\end{array}$ & $\begin{array}{l}-0.293 \\
(0.683)\end{array}$ & $\begin{array}{c}-2.112^{* *} \\
(1.037)\end{array}$ & $\begin{array}{c}-2.315^{* * *} \\
(0.812)\end{array}$ & $\begin{array}{l}0.557 \\
(0.477)\end{array}$ \\
\hline $\begin{array}{l}\text { Ln (Number of Registered } \\
\text { Voters) }\end{array}$ & $\begin{array}{c}-1.076^{* *} \\
(0.434)\end{array}$ & $\begin{array}{l}-0.087 \\
(0.416)\end{array}$ & $\begin{array}{l}-0.262 \\
(0.351)\end{array}$ & $\begin{array}{c}2.436^{* * *} \\
(0.624)\end{array}$ & $\begin{array}{c}2.397^{* * *} \\
(0.947)\end{array}$ & $\begin{array}{c}3.682^{* * *} \\
(0.741)\end{array}$ & $\begin{array}{c}1.280^{* * *} \\
(0.436)\end{array}$ \\
\hline Share of Urban Population & $\begin{array}{c}1.269^{* * *} \\
(0.393)\end{array}$ & $\begin{array}{l}-0.613^{*} \\
(0.376)\end{array}$ & $\begin{array}{l}0.578^{*} \\
(0.318)\end{array}$ & $\begin{array}{c}0.545 \\
(0.565)\end{array}$ & $\begin{array}{c}4.439 * * * \\
(0.857)\end{array}$ & $\begin{array}{c}2.550^{* * *} * \\
(0.671)\end{array}$ & $\begin{array}{c}0.927^{* *} \\
(0.394)\end{array}$ \\
\hline Moscow & $\begin{array}{l}-0.423 \\
(0.313)\end{array}$ & $\begin{array}{c}0.166 \\
(0.300)\end{array}$ & $\begin{array}{c}0.437^{*} \\
(0.253)\end{array}$ & $\begin{array}{c}1.771^{* * *} \\
(0.450)\end{array}$ & $\begin{array}{c}1.323^{* *} \\
(0.683)\end{array}$ & $\begin{array}{c}1.914^{* * * *} \\
(0.535)\end{array}$ & $\begin{array}{c}1.143^{* * * *} \\
(0.314)\end{array}$ \\
\hline Constant & $\begin{array}{l}-0.022 \\
(4.109)\end{array}$ & $\begin{array}{l}6.737^{*} \\
(3.935)\end{array}$ & $\begin{array}{c}2.829 \\
(3.322)\end{array}$ & $\begin{array}{c}11.205^{*} \\
(5.906)\end{array}$ & $\begin{array}{l}-7.245 \\
(8.960)\end{array}$ & $\begin{array}{l}-4.280 \\
(7.016)\end{array}$ & $\begin{array}{c}0.485 \\
(4.123)\end{array}$ \\
\hline Number of observations & 157 & 157 & 157 & 157 & 157 & 157 & 157 \\
\hline "R-squared" & 0,350 & 0,465 & 0,419 & 0,477 & 0,407 & 0,554 & 0,503 \\
\hline BIC & & & & 991,527 & & & \\
\hline
\end{tabular}

Source: author's calculations. Notes. Voting district is used as an unit of observation. During the 2003 parliamentary elections there were 225 votng districts in total. The number of observations is reduced due to the absence of data on corruption. Columns present the results for a particular party. Explanatory variables are given in rows. Standard errors are in parentheses. ${ }^{*}, * *$, and $* * *$ stand for $10 \%, 5 \%$, and $1 \%$ significance levels, respectively. The choice of SUR is justified since the Breusch-Pagan test for independent equations $\left(\mathrm{chi}^{2}(21)=482.482^{* * *}\right)$ rejects the null hypothesis of independence of residuals across the equations. 
Table 8.SUR Estimation of the 2003 Voting Results (Both State Capture Index and Integral CPI are Included)

\begin{tabular}{|c|c|c|c|c|c|c|c|}
\hline & $\begin{array}{l}\text { United } \\
\text { Russia }\end{array}$ & $\begin{array}{c}\text { Communist } \\
\text { Party }\end{array}$ & $\begin{array}{c}\text { Liberal } \\
\text { Democratic } \\
\text { Party }\end{array}$ & $\begin{array}{c}\text { NPU } \\
\text { "Motherland" } \\
\text { ("Rodina") }\end{array}$ & $\begin{array}{c}\text { RDP "Apple" } \\
\text { ("Yabloko") }\end{array}$ & $\begin{array}{c}\text { Union of } \\
\text { Right } \\
\text { Forces } \\
\end{array}$ & Against All \\
\hline & $(1)$ & $(2)$ & $(3)$ & $(4)$ & $(5)$ & $(6)$ & $(7)$ \\
\hline State Capture & $\begin{array}{c}0.051 \\
(0.288)\end{array}$ & $\begin{array}{l}-0.310 \\
(0.283)\end{array}$ & $\begin{array}{l}-0.002 \\
(0.236)\end{array}$ & $\begin{array}{c}-1.452^{* * * *} \\
(0.417)\end{array}$ & $\begin{array}{l}-0.680 \\
(0.624)\end{array}$ & $\begin{array}{l}-0.533 \\
(0.492)\end{array}$ & $\begin{array}{c}-0.623^{* *} \\
(0.289)\end{array}$ \\
\hline Integral CPI & $\begin{array}{c}-0.465^{* * *} \\
(0.133)\end{array}$ & $\begin{array}{c}-0.487^{* * *} \\
(0.130)\end{array}$ & $\begin{array}{c}-0.385^{* * *} \\
(0.109)\end{array}$ & $\begin{array}{l}-0.144 \\
(0.192)\end{array}$ & $\begin{array}{l}-0.183 \\
(0.288)\end{array}$ & $\begin{array}{c}0.006 \\
(0.227)\end{array}$ & $\begin{array}{c}-0.702^{* * *} \\
(0.133)\end{array}$ \\
\hline Ln(Unemployed) & $\begin{array}{c}0.275^{* *} \\
(0.118)\end{array}$ & $\begin{array}{c}0.264^{* *} \\
(0.116)\end{array}$ & $\begin{array}{c}0.554^{* * *} \\
(0.097)\end{array}$ & $\begin{array}{l}0.309^{*} \\
(0.171)\end{array}$ & $\begin{array}{c}0.512^{* *} \\
(0.256)\end{array}$ & $\begin{array}{c}0.205 \\
(0.202)\end{array}$ & $\begin{array}{c}0.457^{* * *} \\
(0.118)\end{array}$ \\
\hline Ln(State Employed) & $\begin{array}{l}-0.224 \\
(0.266)\end{array}$ & $\begin{array}{l}-0.338 \\
(0.261)\end{array}$ & $\begin{array}{c}0.119 \\
(0.218)\end{array}$ & $\begin{array}{c}-1.639^{* * *} \\
(0.385)\end{array}$ & $\begin{array}{l}-0.305 \\
(0.577)\end{array}$ & $\begin{array}{l}-0.151 \\
(0.454)\end{array}$ & $\begin{array}{c}-0.631^{* *} \\
(0.267)\end{array}$ \\
\hline Ln(Privately Employed) & $\begin{array}{c}-0.636^{* *} \\
(0.270)\end{array}$ & $\begin{array}{l}0.485^{*} \\
(0.265)\end{array}$ & $\begin{array}{l}0.422^{*} \\
(0.222)\end{array}$ & $\begin{array}{c}0.146 \\
(0.391)\end{array}$ & $\begin{array}{c}0.638 \\
(0.586)\end{array}$ & $\begin{array}{c}0.989^{* *} \\
(0.462)\end{array}$ & $\begin{array}{l}-0.282 \\
(0.271)\end{array}$ \\
\hline $\operatorname{Ln}$ (Out of the Labor Force) & $\begin{array}{c}1.994^{* * *} \\
(0.446)\end{array}$ & $\begin{array}{c}0.305 \\
(0.437)\end{array}$ & $\begin{array}{l}-0.171 \\
(0.365)\end{array}$ & $\begin{array}{c}-1.390^{* *} \\
(0.645)\end{array}$ & $\begin{array}{c}0.819 \\
(0.967)\end{array}$ & $\begin{array}{c}-2.256^{* * *} \\
(0.761)\end{array}$ & $\begin{array}{l}-0.736^{*} \\
(0.447)\end{array}$ \\
\hline Ln (Real GRP per capita) & $\begin{array}{c}0.465^{* * *} \\
(0.129)\end{array}$ & $\begin{array}{c}0.049 \\
(0.126)\end{array}$ & $\begin{array}{c}0.103 \\
(0.105)\end{array}$ & $\begin{array}{c}0.440^{* *} \\
(0.186)\end{array}$ & $\begin{array}{l}-0.020 \\
(0.279)\end{array}$ & $\begin{array}{l}-0.155 \\
(0.220)\end{array}$ & $\begin{array}{c}0.472^{* * *} \\
(0.129)\end{array}$ \\
\hline Ln (Number of Students) & $\begin{array}{r}-0.191^{*} \\
(0.118)\end{array}$ & $\begin{array}{l}-0.066 \\
(0.116)\end{array}$ & $\begin{array}{c}-0.310^{* * *} \\
(0.097)\end{array}$ & $\begin{array}{l}-0.256 \\
(0.171)\end{array}$ & $\begin{array}{c}-0.596^{* *} \\
(0.257)\end{array}$ & $\begin{array}{l}-0.218 \\
(0.202)\end{array}$ & $\begin{array}{c}-0.272^{* *} \\
(0.119)\end{array}$ \\
\hline Ln (Number of Pensioners) & $\begin{array}{c}0.720 \\
(0.468)\end{array}$ & $\begin{array}{l}-0.460 \\
(0.459)\end{array}$ & $\begin{array}{l}-0.240 \\
(0.383)\end{array}$ & $\begin{array}{l}-0.288 \\
(0.677)\end{array}$ & $\begin{array}{c}-2.762^{* * *} \\
(1.014)\end{array}$ & $\begin{array}{c}-2.957^{* * *} \\
(0.799)\end{array}$ & $\begin{array}{c}0.527 \\
(0.469)\end{array}$ \\
\hline $\begin{array}{l}\text { Ln (Number of Registered } \\
\text { Voters) }\end{array}$ & $\begin{array}{c}-0.964^{* *} \\
(0.437)\end{array}$ & $\begin{array}{l}-0.031 \\
(0.429)\end{array}$ & $\begin{array}{l}-0.082 \\
(0.358)\end{array}$ & $\begin{array}{c}2.568^{* * *} \\
(0.632)\end{array}$ & $\begin{array}{c}2.060^{* *} \\
(0.947)\end{array}$ & $\begin{array}{c}3.359^{* * *} \\
(0.746)\end{array}$ & $\begin{array}{c}1.523^{* * *} \\
(0.438)\end{array}$ \\
\hline Share of Urban Population & $\begin{array}{c}1.175^{* * *} \\
(0.379)\end{array}$ & $\begin{array}{l}-0.693^{*} \\
(0.372)\end{array}$ & $\begin{array}{l}0.555^{*} \\
(0.311)\end{array}$ & $\begin{array}{c}0.377 \\
(0.549)\end{array}$ & $\begin{array}{c}4.264^{* * *} \\
(0.823)\end{array}$ & $\begin{array}{c}2.479^{* * *} \\
(0.648)\end{array}$ & $\begin{array}{c}0.928^{* *} \\
(0.381)\end{array}$ \\
\hline Moscow & $\begin{array}{l}-0.238 \\
(0.292)\end{array}$ & $\begin{array}{c}0.407 \\
(0.287)\end{array}$ & $\begin{array}{c}0.753^{* * *} \\
(0.240)\end{array}$ & $\begin{array}{c}2.027^{* * *} \\
(0.423)\end{array}$ & $\begin{array}{c}1.419^{* *} \\
(0.634)\end{array}$ & $\begin{array}{c}1.803^{* * *} \\
(0.499)\end{array}$ & $\begin{array}{c}1.519^{* * *} \\
(0.294)\end{array}$ \\
\hline Constant & $\begin{array}{l}-2.021 \\
(1.972)\end{array}$ & $\begin{array}{c}0.508 \\
(1.936)\end{array}$ & $\begin{array}{l}-2.029 \\
(1.617)\end{array}$ & $\begin{array}{l}-5.233^{*} \\
(2.855)\end{array}$ & $\begin{array}{c}-6.792 \\
(4.278)\end{array}$ & $\begin{array}{l}-4.957 \\
(3.369)\end{array}$ & $\begin{array}{c}-9.265^{* * *} \\
(1.980)\end{array}$ \\
\hline Number of observations & 154 & 154 & 154 & 154 & 154 & 154 & 154 \\
\hline "R-squared" & 0,333 & 0,410 & 0,388 & 0,456 & 0,397 & 0,542 & 0,482 \\
\hline
\end{tabular}

Source: author's calculations. Notes. Voting district is used as an unit of observation. During the 2003 parliamentary elections there were 225 votng districts in total. The number of observations is reduced due to the absence of data on corruption. Columns present the results for a particular party. Explanatory variables are given in rows. Standard errors are in parentheses. ${ }^{* * *}$, and $* * *$ stand for $10 \%, 5 \%$, and $1 \%$ significance levels, respectively. The choice of SUR is justified since the Breusch-Pagan test for independent equations $\left(\mathrm{chi}^{2}(21)=450.094^{* * *}\right)$ rejects the null hypothesis of independence of residuals across the equations. 
Table 9. SUR Estimation of the 1999 Voting Results (State Capture Index is Used to Control for Corruption)

\begin{tabular}{|c|c|c|c|c|c|c|c|}
\hline & $\begin{array}{l}\text { IRP "Unity" } \\
\text { ("Yedinstvo") }\end{array}$ & $\begin{array}{l}\text { Communist } \\
\text { Party }\end{array}$ & $\begin{array}{c}\text { Liberal } \\
\text { Democratic } \\
\text { Party }\end{array}$ & Otechestvo & $\begin{array}{c}\text { RDP } \\
\text { "Apple" } \\
\text { ("Yabloko") }\end{array}$ & $\begin{array}{l}\text { Union of } \\
\text { Right } \\
\text { Forces } \\
\end{array}$ & Against All \\
\hline & $(1)$ & $(2)$ & $(3)$ & $(4)$ & $(5)$ & $(6)$ & $(7)$ \\
\hline State Capture & $\begin{array}{l}4.545^{*} \\
(2.801)\end{array}$ & $\begin{array}{c}8.519^{* * *} \\
(2.774)\end{array}$ & $\begin{array}{c}1.030 \\
(1.532)\end{array}$ & $\begin{array}{l}-3.288 \\
(6.481)\end{array}$ & $\begin{array}{c}0.489 \\
(3.552)\end{array}$ & $\begin{array}{c}0.179 \\
(3.123)\end{array}$ & $\begin{array}{c}1.893 \\
(1.966)\end{array}$ \\
\hline Ln(Unemployed) & $\begin{array}{c}0.588^{* *} \\
(0.276)\end{array}$ & $\begin{array}{c}0.410 \\
(0.274)\end{array}$ & $\begin{array}{c}0.852^{* * *} \\
(0.250)\end{array}$ & $\begin{array}{c}-1.940^{* * *} \\
(0.639)\end{array}$ & $\begin{array}{c}1.189^{* * *} \\
(0.350)\end{array}$ & $\begin{array}{c}0.906^{* * *} \\
(0.308)\end{array}$ & $\begin{array}{c}0.715^{* * *} \\
(0.194)\end{array}$ \\
\hline Ln(State Employed) & $\begin{array}{l}-0.390 \\
(0.370)\end{array}$ & $\begin{array}{l}-0.295 \\
(0.366)\end{array}$ & $\begin{array}{l}-0.389 \\
(0.335)\end{array}$ & $\begin{array}{l}1.849^{* *} \\
(0.856)\end{array}$ & $\begin{array}{c}-1.168^{* *} \\
(0.469)\end{array}$ & $\begin{array}{c}-0.920^{* *} \\
(0.413)\end{array}$ & $\begin{array}{l}-0.277 \\
(0.260)\end{array}$ \\
\hline Ln(Privately Employed) & $\begin{array}{c}0.107 \\
(0.258)\end{array}$ & $\begin{array}{l}-0.345 \\
(0.255)\end{array}$ & $\begin{array}{c}0.239 \\
(0.233)\end{array}$ & $\begin{array}{l}-1.012^{*} \\
(0.596)\end{array}$ & $\begin{array}{c}0.420 \\
(0.327)\end{array}$ & $\begin{array}{l}-0.145 \\
(0.287)\end{array}$ & $\begin{array}{l}0.269 \\
(0.181)\end{array}$ \\
\hline $\operatorname{Ln}$ (Out of the Labor Force) & $\begin{array}{c}0.811 \\
(0.561)\end{array}$ & $\begin{array}{c}0.327 \\
(0.556)\end{array}$ & $\begin{array}{c}0.461 \\
(0.507)\end{array}$ & $\begin{array}{l}-1.400 \\
(1.298)\end{array}$ & $\begin{array}{l}-0.889 \\
(0.711)\end{array}$ & $\begin{array}{c}0.166 \\
(0.625)\end{array}$ & $\begin{array}{l}-0.592 \\
(0.394)\end{array}$ \\
\hline $\begin{array}{l}\text { State Capture* } \\
\text { Ln(Unemployed) }\end{array}$ & $\begin{array}{l}-0.192 \\
(0.627)\end{array}$ & $\begin{array}{l}-0.445 \\
(0.621)\end{array}$ & $\begin{array}{c}-1.982^{* * *} \\
(0.567)\end{array}$ & $\begin{array}{l}2.248 \\
(1.452)\end{array}$ & $\begin{array}{c}-2.750^{* * *} \\
(0.796)\end{array}$ & $\begin{array}{c}-2.758^{* * *} \\
(0.700)\end{array}$ & $\begin{array}{c}-2.108^{* * *} \\
(0.440)\end{array}$ \\
\hline $\begin{array}{l}\text { State Capture* } \\
\text { Ln(State Employed) }\end{array}$ & $\begin{array}{l}0.947 \\
(0.997)\end{array}$ & $\begin{array}{l}-0.698 \\
(0.988)\end{array}$ & $\begin{array}{c}2.890^{* * *} \\
(0.902)\end{array}$ & $\begin{array}{l}-3.120 \\
(2.307)\end{array}$ & $\begin{array}{c}3.527^{* * *} \\
(1.264)\end{array}$ & $\begin{array}{c}2.295^{* *} \\
(1.112)\end{array}$ & $\begin{array}{c}1.640^{* *} \\
(0.700)\end{array}$ \\
\hline $\begin{array}{l}\text { State Capture* } \\
\text { Ln(Privately Employed) }\end{array}$ & $\begin{array}{l}-0.676 \\
(0.705)\end{array}$ & $\begin{array}{l}-0.504 \\
(0.699)\end{array}$ & $\begin{array}{l}-0.793 \\
(0.638)\end{array}$ & $\begin{array}{c}0.398 \\
(1.632)\end{array}$ & $\begin{array}{c}-2.076^{* *} \\
(0.894)\end{array}$ & $\begin{array}{c}0.094 \\
(0.786)\end{array}$ & $\begin{array}{l}-0.952^{*} \\
(0.495)\end{array}$ \\
\hline $\begin{array}{l}\text { State Capture* } \\
\operatorname{Ln} \text { (Out of the Labor Force) }\end{array}$ & $\begin{array}{l}-1.473 \\
(0.977)\end{array}$ & $\begin{array}{l}-0.274 \\
(0.968)\end{array}$ & $\begin{array}{l}-0.993 \\
(0.884)\end{array}$ & $\begin{array}{l}2.256 \\
(2.262)\end{array}$ & $\begin{array}{c}1.106 \\
(1.240)\end{array}$ & $\begin{array}{l}-0.238 \\
(1.090)\end{array}$ & $\begin{array}{c}0.886 \\
(0.686)\end{array}$ \\
\hline Ln (Real GRP per capita) & $\begin{array}{c}-0.277^{* * *} \\
(0.087)\end{array}$ & $\begin{array}{c}-0.316^{* * *} \\
(0.086)\end{array}$ & $\begin{array}{l}-0.043 \\
(0.078)\end{array}$ & $\begin{array}{c}0.078 \\
(0.201)\end{array}$ & $\begin{array}{l}-0.025 \\
(0.110)\end{array}$ & $\begin{array}{c}0.126 \\
(0.097)\end{array}$ & $\begin{array}{l}-0.070 \\
(0.061)\end{array}$ \\
\hline Ln (Students) & $\begin{array}{c}0.092 \\
(0.093)\end{array}$ & $\begin{array}{l}0.174^{*} \\
(0.092)\end{array}$ & $\begin{array}{c}-0.394^{* * *} \\
(0.084)\end{array}$ & $\begin{array}{c}0.307 \\
(0.214)\end{array}$ & $\begin{array}{c}0.126 \\
(0.117)\end{array}$ & $\begin{array}{l}0.167^{*} \\
(0.103)\end{array}$ & $\begin{array}{c}-0.159^{* *} \\
(0.065)\end{array}$ \\
\hline Ln (Pensioners) & $\begin{array}{l}-0.157 \\
(0.286)\end{array}$ & $\begin{array}{c}0.785^{* * *} \\
(0.285)\end{array}$ & $\begin{array}{l}-0.317 \\
(0.259)\end{array}$ & $\begin{array}{c}2.010^{* * *} \\
(0.663)\end{array}$ & $\begin{array}{c}0.381 \\
(0.363)\end{array}$ & $\begin{array}{c}0.076 \\
(0.319)\end{array}$ & $\begin{array}{c}0.117 \\
(0.201)\end{array}$ \\
\hline $\begin{array}{l}\text { Ln (Number of Registered } \\
\text { Voters) }\end{array}$ & $\begin{array}{c}0.004 \\
(0.054)\end{array}$ & $\begin{array}{l}-0.012 \\
(0.053)\end{array}$ & $\begin{array}{l}-0.018 \\
(0.048)\end{array}$ & $\begin{array}{c}0.034 \\
(0.124)\end{array}$ & $\begin{array}{c}0.000 \\
(0.068)\end{array}$ & $\begin{array}{l}-0.004 \\
(0.060)\end{array}$ & $\begin{array}{l}-0.010 \\
(0.038)\end{array}$ \\
\hline Share of Urban Population & $\begin{array}{c}-0.832^{* * *} \\
(0.301)\end{array}$ & $\begin{array}{l}-1.959^{* * *} \\
(0.298)\end{array}$ & $\begin{array}{c}0.082 \\
(0.272)\end{array}$ & $\begin{array}{c}0.444 \\
(0.697)\end{array}$ & $\begin{array}{c}1.566^{* * *} \\
(0.382)\end{array}$ & $\begin{array}{c}1.528^{* * *} \\
(0.336)\end{array}$ & $\begin{array}{c}0.971^{* * *} \\
(0.212)\end{array}$ \\
\hline Moscow & $\begin{array}{c}0.161 \\
(0.224)\end{array}$ & $\begin{array}{c}0.943^{* * *} \\
(0.222)\end{array}$ & $\begin{array}{l}0.374^{*} \\
(0.202)\end{array}$ & $\begin{array}{c}0.827 \\
(0.518)\end{array}$ & $\begin{array}{c}0.983^{* * *} \\
(0.284)\end{array}$ & $\begin{array}{c}0.304 \\
(0.250)\end{array}$ & $\begin{array}{c}0.648^{* * *} \\
(0.157)\end{array}$ \\
\hline Constant & $\begin{array}{l}-1.168 \\
(1.371)\end{array}$ & $\begin{array}{l}-1.222 \\
(1.358)\end{array}$ & $\begin{array}{l}-1.985 \\
(1.240)\end{array}$ & $\begin{array}{l}-1.137 \\
(3.173)\end{array}$ & $\begin{array}{l}-2.562 \\
(1.739)\end{array}$ & $\begin{array}{l}-1.891 \\
(1.529)\end{array}$ & $\begin{array}{c}-2.770^{* * *} \\
(0.963)\end{array}$ \\
\hline Number of observations & 205 & 205 & 205 & 205 & 205 & 205 & 205 \\
\hline "R-squared" & 0,496 & 0,507 & 0,295 & 0,486 & 0,360 & 0,377 & 0,375 \\
\hline \multicolumn{4}{|l|}{$\mathrm{BIC}$} & \multicolumn{3}{|l|}{1424,558} & \\
\hline \multicolumn{8}{|c|}{$\begin{array}{l}\text { Source: author's calculations. Notes. Voting district is used as an unit of observation. During the } 1999 \text { parliamentary } \\
\text { elections there were } 224 \text { votng districts in total. The number of observations is reduced due to the absence of data on } \\
\text { corruption. Columns present the results for a particular party. Explanatory variables are given in rows. Standard errors are } \\
\text { in parentheses. } * * * \text {, and } * * * \text { stand for } 10 \%, 5 \% \text {, and } 1 \% \text { significance levels, respectively. The choice of SUR is justified } \\
\text { since the Breusch-Pagan test for independent equations }\left(\mathrm{chi}^{2}(21)=605.232^{* * *}\right) \text { rejects the null hypothesis of independence } \\
\text { of residuals across the equations. }\end{array}$} \\
\hline
\end{tabular}


Table 10. Participation in Elections

\begin{tabular}{|c|c|c|c|}
\hline \multirow{2}{*}{$\begin{array}{l}\text { Dependent Variable: } \\
\text { Ln(Number Participated) }\end{array}$} & \multicolumn{2}{|c|}{ State Capture } & \multirow{2}{*}{$\begin{array}{c}\text { Integral CPI } \\
2003 \\
\end{array}$} \\
\hline & 1999 & 2003 & \\
\hline Corruption & $\begin{array}{l}-0.072 \\
(0.575)\end{array}$ & $\begin{array}{l}4.803^{*} \\
(2.827)\end{array}$ & $\begin{array}{c}2.468 \\
(3.723)\end{array}$ \\
\hline Ln(Unemployed) & $\begin{array}{c}-0.189^{* * *} \\
(0.060)\end{array}$ & $\begin{array}{l}0.154^{*} \\
(0.096)\end{array}$ & $\begin{array}{l}-0.063 \\
(0.110)\end{array}$ \\
\hline Ln(State Employed) & $\begin{array}{c}0.329^{* * *} \\
(0.082)\end{array}$ & $\begin{array}{c}0.234 \\
(0.203)\end{array}$ & $\begin{array}{c}0.227 \\
(0.158)\end{array}$ \\
\hline Ln(Privately Employed) & $\begin{array}{l}-0.086 \\
(0.083)\end{array}$ & $\begin{array}{l}-0.032 \\
(0.208)\end{array}$ & $\begin{array}{l}-0.066 \\
(0.139)\end{array}$ \\
\hline Ln(Out of the Labor Force) & $\begin{array}{c}0.149 \\
(0.150)\end{array}$ & $\begin{array}{c}0.349 \\
(0.257)\end{array}$ & $\begin{array}{c}0.552 \\
(0.368)\end{array}$ \\
\hline Corruption*Ln(Unemployed) & $\begin{array}{c}0.428^{* * *} \\
(0.124)\end{array}$ & $\begin{array}{c}-0.787^{* *} \\
(0.311)\end{array}$ & $\begin{array}{c}-0.097 \\
(0.253)\end{array}$ \\
\hline Corruption*Ln(State Employed) & $\begin{array}{l}-0.229 \\
(0.199)\end{array}$ & $\begin{array}{c}0.070 \\
(0.716)\end{array}$ & $\begin{array}{c}-0.291 \\
(0.422)\end{array}$ \\
\hline Corruption*Ln(Privately Employed) & $\begin{array}{c}0.081 \\
(0.181)\end{array}$ & $\begin{array}{l}-0.792 \\
(0.756)\end{array}$ & $\begin{array}{c}-0.668^{* * *} \\
(0.278)\end{array}$ \\
\hline Corruption*Ln(Out of the Labor Force) & $\begin{array}{l}-0.280 \\
(0.265)\end{array}$ & $\begin{array}{c}0.525 \\
(0.623)\end{array}$ & $\begin{array}{c}0.811 \\
(0.626)\end{array}$ \\
\hline Ln (Real GRP per capita) & $\begin{array}{l}-0.006 \\
(0.019)\end{array}$ & $\begin{array}{c}0.005 \\
(0.038)\end{array}$ & $\begin{array}{c}0.097^{* *} \\
(0.049)\end{array}$ \\
\hline Ln (Number of Students) & $\begin{array}{l}0.040^{*} \\
(0.023)\end{array}$ & $\begin{array}{c}0.018 \\
(0.040)\end{array}$ & $\begin{array}{l}-0.020 \\
(0.033)\end{array}$ \\
\hline Ln (Number of Pensioners) & $\begin{array}{c}0.751^{* * *} \\
(0.069)\end{array}$ & $\begin{array}{c}0.222 \\
(0.140)\end{array}$ & $\begin{array}{c}0.389 * * \\
(0.160)\end{array}$ \\
\hline Ln (Number of Registered Voters) & $\begin{array}{c}0.013 \\
(0.015)\end{array}$ & $\begin{array}{c}0.520^{* * *} \\
(0.129)\end{array}$ & $\begin{array}{c}0.589^{* * *} \\
(0.155)\end{array}$ \\
\hline Share of Urban Population & $\begin{array}{c}-0.345^{* * *} \\
(0.080)\end{array}$ & $\begin{array}{c}-0.434^{* * *} \\
(0.118)\end{array}$ & $\begin{array}{c}-0.373^{* * *} \\
(0.131)\end{array}$ \\
\hline Moscow & $\begin{array}{c}0.067 \\
(0.046)\end{array}$ & $\begin{array}{c}-0.552^{* * *} \\
(0.195)\end{array}$ & $\begin{array}{c}-0.276^{* *} \\
(0.121)\end{array}$ \\
\hline Constant & $\begin{array}{c}0.998^{* * *} \\
(0.330)\end{array}$ & $\begin{array}{c}-1.220 \\
(0.938)\end{array}$ & $\begin{array}{c}-2.517 \\
(1.677)\end{array}$ \\
\hline R-squared & 0,859 & 0,828 & 0,694 \\
\hline Number of observations & 205 & 205 & 157 \\
\hline $\mathrm{BIC}$ & $-322,095$ & $-244,846$ & $-194,498$ \\
\hline $\begin{array}{l}\text { Source: author's calculations. Notes. } \\
\text { corruption are used: state capture and } \\
\text { CPI). Columns present the results for ea } \\
\text { is used as an unit of observation. There } \\
\text { elections and } 224 \text { voting districts during } \\
\text { reduced due to the absence of data on } \\
\text { variables are given in rows. Robust stanc } \\
\text { for } 10 \%, 5 \% \text {, and } 1 \% \text { significance levels, }\end{array}$ & $\begin{array}{l}\text { esents OL } \\
\text { corruption } \\
\text { measures } \\
\text { votng dist } \\
\text { elections. } \\
\text { a for some } \\
\text { s are in pa } \\
\text { ely. }\end{array}$ & $\begin{array}{l}\text { repults. } \mathrm{Th} \\
\text { rceptions } \\
\text { orruption. } \\
\text { in total } \\
\text { number of } \\
\text { ing distric } \\
\text { heses. } * * *\end{array}$ & $\begin{array}{l}\text { measures of } \\
\text { ndex (integral } \\
\text { Voting district } \\
\text { uring the } 2003 \\
\text { observations is } \\
\text { s. Explanatory } \\
\text { and } * * * \text { stand }\end{array}$ \\
\hline
\end{tabular}


Table 11. Artificial Outcomes of the 2003 Elections for Different Values of State Capture.

Political party

Mean St. error $95 \%$ Confidence Interval

\begin{tabular}{lcccc}
\hline \multicolumn{5}{c}{ State Capture at mean, All other explanatory variables at their mean } \\
\hline United Russia & 0,3819 & 0,0811 & 0,2302 & 0,5512 \\
Communist Party of the Russian Federation (CPRF) & 0,1286 & 0,0313 & 0,0768 & 0,2032 \\
Liberal Democratic Party of Russia (LDPR) & 0,1053 & 0,0340 & 0,0528 & 0,1814 \\
National-Patriotic Union "Motherland" ("Rodina") & 0,0976 & 0,0315 & 0,0457 & 0,1680 \\
Russian Democratic Party "Apple" ("Yabloko") & 0,0500 & 0,0292 & 0,0145 & 0,1304 \\
The Union of Right Forces & 0,0429 & 0,0224 & 0,0127 & 0,0991 \\
Votes against All Parties & 0,0463 & 0,0125 & 0,0262 & 0,0748 \\
\hline \multicolumn{4}{c}{ State Capture at max, All other explanatory variables at their mean } \\
\hline United Russia & 0,3189 & 0,0988 & 0,1436 & 0,5311 \\
Communist Party of the Russian Federation (CPRF) & 0,1628 & 0,0544 & 0,0768 & 0,2887 \\
Liberal Democratic Party of Russia (LDPR) & 0,2428 & 0,0847 & 0,1075 & 0,4360 \\
National-Patriotic Union "Motherland" ("Rodina") & 0,0378 & 0,0178 & 0,0132 & 0,0793 \\
Russian Democratic Party "Apple" ("Yabloko") & 0,0289 & 0,0254 & 0,0044 & 0,0984 \\
The Union of Right Forces & 0,0118 & 0,0105 & 0,0021 & 0,0392 \\
Votes against All Parties & 0,0494 & 0,0200 & 0,0216 & 0,0956 \\
\hline \multicolumn{4}{c}{ State Capture at min, All other explanatory variables at their mean } \\
\hline United Russia & 0,3402 & 0,0793 & 0,1979 & 0,5024 \\
Communist Party of the Russian Federation (CPRF) & 0,1386 & 0,0329 & 0,0847 & 0,2130 \\
Liberal Democratic Party of Russia (LDPR) & 0,1120 & 0,0358 & 0,0565 & 0,1939 \\
National-Patriotic Union "Motherland" ("Rodina") & 0,1187 & 0,0381 & 0,0576 & 0,2056 \\
Russian Democratic Party "Apple" ("Yabloko") & 0,0555 & 0,0346 & 0,0140 & 0,1522 \\
The Union of Right Forces & 0,0406 & 0,0233 & 0,0126 & 0,0993 \\
Votes against All Parties & 0,0453 & 0,0126 & 0,0250 & 0,0725 \\
\hline \hline
\end{tabular}

Source: author's calculations. Notes: Simulations have been done using CLARIFY software. First, SUR

system has been estimated and 1000 sets of simulated coefficients has been drawn. Predicted voting shares for each party have been calculated based on sets of simulated coefficients and different values of corruption measure and means of other explanatory variables. 
Table 12. Artificial Outcomes of the 2003 Elections for Different Values of Integral CPI.

\begin{tabular}{|c|c|c|c|c|}
\hline $\begin{array}{l}\text { Political party } \\
\end{array}$ & $\overline{\text { Mean }}$ & $\overline{\text { St. error }}$ & $\overline{95 \% \mathrm{Con}}$ & e Interval \\
\hline \multicolumn{5}{|c|}{ Integral CPI at mean, All other explanatory variables at their mean } \\
\hline United Russia & 0,3712 & 0,0684 & 0,2516 & 0,5038 \\
\hline Communist Party of the Russian Federation (CPRF) & 0,1174 & 0,0258 & 0,0719 & 0,1717 \\
\hline Liberal Democratic Party of Russia (LDPR) & 0,1188 & 0,0228 & 0,0793 & 0,1637 \\
\hline National-Patriotic Union "Motherland" ("Rodina") & 0,1094 & 0,0356 & 0,0528 & 0,1918 \\
\hline Russian Democratic Party "Apple" ("Yabloko") & 0,0486 & 0,0314 & 0,0118 & 0,1334 \\
\hline The Union of Right Forces & 0,0351 & 0,0168 & 0,0121 & 0,0768 \\
\hline Votes against All Parties & 0,0541 & 0,0124 & 0,0331 & 0,0810 \\
\hline \multicolumn{5}{|c|}{ Integral CPI at max, All other explanatory variables at their mean } \\
\hline United Russia & 0,3864 & 0,0716 & 0,2482 & 0,5287 \\
\hline Communist Party of the Russian Federation (CPRF) & 0,1417 & 0,0309 & 0,0903 & 0,2127 \\
\hline Liberal Democratic Party of Russia (LDPR) & 0,1277 & 0,0263 & 0,0824 & 0,1842 \\
\hline National-Patriotic Union "Motherland" ("Rodina") & 0,0818 & 0,0283 & 0,0390 & 0,1480 \\
\hline Russian Democratic Party "Apple" ("Yabloko") & 0,0438 & 0,0300 & 0,0090 & 0,1198 \\
\hline The Union of Right Forces & 0,0298 & 0,0159 & 0,0101 & 0,0709 \\
\hline Votes against All Parties & 0,0613 & 0,0151 & 0,0369 & 0,0958 \\
\hline \multicolumn{5}{|c|}{ Integral CPI at min, All other explanatory variables at their mean } \\
\hline United Russia & 0,3917 & 0,1007 & 0,1944 & 0,5892 \\
\hline Communist Party of the Russian Federation (CPRF) & 0,0633 & 0,0203 & 0,0303 & 0,1060 \\
\hline Liberal Democratic Party of Russia (LDPR) & 0,0930 & 0,0272 & 0,0492 & 0,1541 \\
\hline National-Patriotic Union "Motherland" ("Rodina") & 0,0643 & 0,0316 & 0,0216 & 0,1451 \\
\hline Russian Democratic Party "Apple" ("Yabloko") & 0,0749 & 0,0689 & 0,0098 & 0,2813 \\
\hline The Union of Right Forces & 0,0512 & 0,0376 & 0,0109 & 0,1524 \\
\hline Votes against All Parties & 0,0304 & 0,0100 & 0,0148 & 0,0535 \\
\hline
\end{tabular}

Source: author's calculations. Notes: Simulations have been done using CLARIFY software. First, SUR system has been estimated and 1000 sets of simulated coefficients has been drawn. Predicted voting shares for each party have been calculated based on sets of simulated coefficients and different values of corruption measure and means of other explanatory variables. 


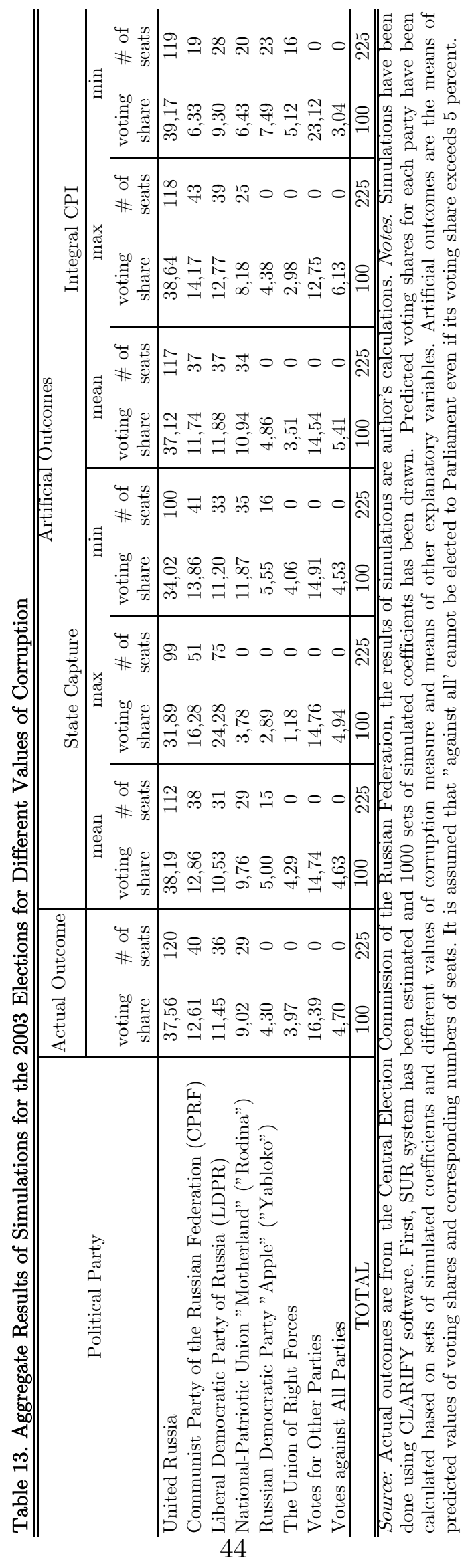


Table 14. Artificial Outcomes of the 1999 Elections for Different Values of State Capture.

\begin{tabular}{lcccc}
\multicolumn{1}{c}{ Political party } & Mean & St. error & $95 \%$ Confidence Interval \\
\hline \hline \multicolumn{1}{c}{ State Capture at mean, All other explanatory variables at their mean } \\
\hline IRP "Unity" ("Yedinstvo") & 0,0965 & 0,0720 & 0,0094 & 0,2797 \\
Communist Party of the Russian Federation (CPRF) & 0,0945 & 0,0586 & 0,0149 & 0,2320 \\
Liberal Democratic Party (Zhirinovsky's block) & 0,0241 & 0,0180 & 0,0032 & 0,0677 \\
Otechestvo-All Russia & 0,6746 & 0,1846 & 0,2670 & 0,9425 \\
Russian Democratic Party "Apple" ("Yabloko") & 0,0203 & 0,0123 & 0,0049 & 0,0506 \\
The Union of Right Forces & 0,0306 & 0,0184 & 0,0068 & 0,0772 \\
Votes against All Parties & 0,0121 & 0,0062 & 0,0027 & 0,0260 \\
\hline \multicolumn{4}{c}{ State Capture at max, All other explanatory variables at their mean } \\
\hline IRP "Unity" ("Yedinstvo") & 0,1237 & 0,0859 & 0,0124 & 0,3351 \\
Communist Party of the Russian Federation (CPRF) & 0,1292 & 0,0711 & 0,0211 & 0,2880 \\
Liberal Democratic Party (Zhirinovsky's block) & 0,0310 & 0,0213 & 0,0036 & 0,0858 \\
Otechestvo-All Russia & 0,5771 & 0,2108 & 0,1580 & 0,9201 \\
Russian Democratic Party "Apple" ("Yabloko") & 0,0290 & 0,0163 & 0,0063 & 0,0708 \\
The Union of Right Forces & 0,0452 & 0,0251 & 0,0077 & 0,1050 \\
Votes against All Parties & 0,0142 & 0,0067 & 0,0031 & 0,0287 \\
\hline \multicolumn{4}{c}{ State Capture at min, All other explanatory variables at their mean } \\
\hline IRP "Unity" ("Yedinstvo") & 0,0921 & 0,0715 & 0,0082 & 0,2855 \\
Communist Party of the Russian Federation (CPRF) & 0,0880 & 0,0568 & 0,0113 & 0,2250 \\
Liberal Democratic Party (Zhirinovsky's block) & 0,0229 & 0,0165 & 0,0027 & 0,0646 \\
Otechestvo-All Russia & 0,6951 & 0,1817 & 0,2750 & 0,9513 \\
Russian Democratic Party "Apple" ("Yabloko") & 0,0177 & 0,0109 & 0,0037 & 0,0450 \\
The Union of Right Forces & 0,0269 & 0,0170 & 0,0046 & 0,0722 \\
Votes against All Parties & 0,0116 & 0,0062 & 0,0022 & 0,0262 \\
\hline \hline
\end{tabular}

Source: author's calculations. Notes: Simulations have been done using CLARIFY software. First, SUR system has been estimated and 1000 sets of simulated coefficients has been drawn. Predicted voting shares for each party have been calculated based on sets of simulated coefficients and different values of corruption measure and means of other explanatory variables. 


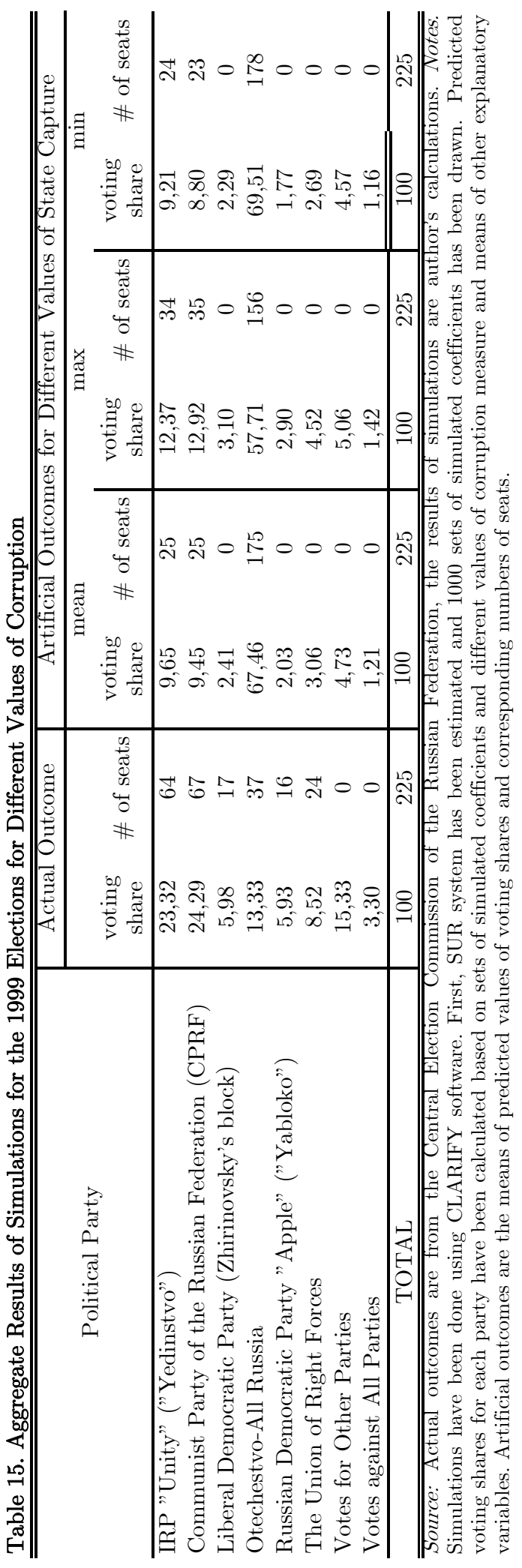




\section{Supplementary Tables}

Table 6a. Sensitivity Check for the Estimation Results from the 2003 (State Capture Index is Used to Control for Corruption)

\begin{tabular}{|c|c|c|c|c|}
\hline & Party of Power & Anti-Reform & Pro-Reform & Protest Voting \\
\hline & (1) & $(2)$ & (3) & $(4)$ \\
\hline State Capture & $\begin{array}{c}-14.783 \\
(13.070)\end{array}$ & $\begin{array}{c}-3.525 \\
(11.368)\end{array}$ & $\begin{array}{l}44.405^{* *} \\
(19.940)\end{array}$ & $\begin{array}{c}-16.764^{*} \\
(10.488)\end{array}$ \\
\hline Ln(Unemployed) & $\begin{array}{c}1.117^{* * *} \\
(0.378)\end{array}$ & $\begin{array}{c}0.091 \\
(0.328)\end{array}$ & $\begin{array}{l}-0.742 \\
(0.576)\end{array}$ & $\begin{array}{c}0.267 \\
(0.303)\end{array}$ \\
\hline Ln(State Employed) & $\begin{array}{c}-1.497 \\
(1.450)\end{array}$ & $\begin{array}{l}-1.220 \\
(1.261)\end{array}$ & $\begin{array}{c}4.819^{* *} \\
(2.212)\end{array}$ & $\begin{array}{c}-3.036^{* * *} \\
(1.163)\end{array}$ \\
\hline Ln(Privately Employed) & $\begin{array}{l}-0.269 \\
(0.997)\end{array}$ & $\begin{array}{c}0.054 \\
(0.867)\end{array}$ & $\begin{array}{c}4.046^{* * *} \\
(1.521)\end{array}$ & $\begin{array}{c}-1.511^{*} \\
(0.800)\end{array}$ \\
\hline $\operatorname{Ln}$ (Out of the Labor Force) & $\begin{array}{c}-0.792 \\
(2.242)\end{array}$ & $\begin{array}{c}1.175 \\
(1.950)\end{array}$ & $\begin{array}{c}-8.992^{* * *} \\
(3.420)\end{array}$ & $\begin{array}{c}4.428^{* *} \\
(1.799)\end{array}$ \\
\hline State Capture*Ln(Unemployed) & $\begin{array}{c}-3.551^{* * *} \\
(0.957)\end{array}$ & $\begin{array}{c}0.481 \\
(1.178)\end{array}$ & $\begin{array}{l}3.438^{*} \\
(2.066)\end{array}$ & $\begin{array}{c}0.368 \\
(1.087)\end{array}$ \\
\hline State Capture*Ln(State Employed) & $\begin{array}{c}9.144^{*} \\
(5.512)\end{array}$ & $\begin{array}{c}2.833 \\
(4.794)\end{array}$ & $\begin{array}{c}-17.836^{* *} \\
(8.410)\end{array}$ & $\begin{array}{c}6.772 \\
(4.423)\end{array}$ \\
\hline State Capture*Ln(Privately Employed) & $\begin{array}{c}2.768 \\
(3.075)\end{array}$ & $\begin{array}{l}1.915 \\
(2.674)\end{array}$ & $\begin{array}{c}-11.482^{* *} \\
(4.691)\end{array}$ & $\begin{array}{c}3.734 \\
(2.467)\end{array}$ \\
\hline State Capture* $\operatorname{Ln}($ Out of the Labor Force) & $\begin{array}{c}-9.469 \\
(7.277)\end{array}$ & $\begin{array}{l}-6.566 \\
(6.329)\end{array}$ & $\begin{array}{c}26.816^{* *} \\
(11.101)\end{array}$ & $\begin{array}{c}-11.129^{*} \\
(5.839)\end{array}$ \\
\hline Ln (Real GRP per capita) & $\begin{array}{c}0.043 \\
(0.134)\end{array}$ & $\begin{array}{l}-0.150 \\
(0.117)\end{array}$ & $\begin{array}{c}0.202 \\
(0.205)\end{array}$ & $\begin{array}{l}0.189^{*} \\
(0.108)\end{array}$ \\
\hline Ln (Students) & $\begin{array}{c}0.383^{* * *} \\
(0.122)\end{array}$ & $\begin{array}{c}0.091 \\
(0.106)\end{array}$ & $\begin{array}{l}-0.038 \\
(0.186)\end{array}$ & $\begin{array}{c}-0.432^{* * *} \\
(0.098)\end{array}$ \\
\hline Ln (Pensioners) & $\begin{array}{c}1.304^{* * * *} \\
(0.494)\end{array}$ & $\begin{array}{l}-0.213 \\
(0.429)\end{array}$ & $\begin{array}{c}-2.137^{* * *} \\
(0.753)\end{array}$ & $\begin{array}{c}-0.535 \\
(0.396)\end{array}$ \\
\hline Ln (Number of Registered Voters) & $\begin{array}{c}0.445 \\
(0.409)\end{array}$ & $\begin{array}{c}0.624^{*} \\
(0.356)\end{array}$ & $\begin{array}{c}2.658^{* * * *} \\
(0.624)\end{array}$ & $\begin{array}{c}0.940^{* * * *} \\
(0.328)\end{array}$ \\
\hline Share of Urban Population & $\begin{array}{l}0.638^{*} \\
(0.367)\end{array}$ & $\begin{array}{c}-0.773^{* *} \\
(0.319)\end{array}$ & $\begin{array}{c}2.696^{* * * *} \\
(0.559)\end{array}$ & $\begin{array}{c}0.959^{* * * *} \\
(0.294)\end{array}$ \\
\hline Moscow & $\begin{array}{l}-0.395 \\
(0.684)\end{array}$ & $\begin{array}{c}1.338^{* *} \\
(0.595)\end{array}$ & $\begin{array}{c}1.305 \\
(1.043)\end{array}$ & $\begin{array}{c}1.817^{* * *} \\
(0.549)\end{array}$ \\
\hline Constant & $\begin{array}{c}-3.292 \\
(4.365)\end{array}$ & $\begin{array}{c}-0.671 \\
(3.796)\end{array}$ & $\begin{array}{c}-20.550^{* * *} \\
(6.659)\end{array}$ & $\begin{array}{c}4.368 \\
(3.502)\end{array}$ \\
\hline Number of observations & 205 & 205 & 205 & 205 \\
\hline "R-squared" & 0,219 & 0,332 & 0,406 & 0,356 \\
\hline
\end{tabular}

Source: author's calculations. Notes. Voting district is used as an unit of observation. During the 2003 parliamentary elections there were 225 votng districts in total. The number of observations is reduced due to the absence of data on corruption. Columns present the results for a particular group of parties. Explanatory variables are given in rows. Standard errors are in parantheses. ***, and *** stand for $10 \%, 5 \%$, and $1 \%$ significance levels, respectively. The choice of SUR is justified since the Breusch-Pagan test for independent equations $\left(\operatorname{chi}^{2}(6)=123.957^{* * *}\right)$ rejects the null hypothesis of independence of residuals across the equations. 
Table 7a. Sensitivity Check for the Estimation Results from the 2003 (Integral CPI is Used to Control for Corruption)

\begin{tabular}{|c|c|c|c|c|}
\hline & Party of Power & Anti-Reform & Pro-Reform & $\begin{array}{l}\text { Protest Voting } \\
\end{array}$ \\
\hline & $(1)$ & $(2)$ & $(3)$ & $(4)$ \\
\hline Integral CPI & $\begin{array}{c}5.832 \\
(12.396)\end{array}$ & $\begin{array}{c}25.920^{* *} \\
(11.200)\end{array}$ & $\begin{array}{c}-5.326 \\
(24.113)\end{array}$ & $\begin{array}{c}-2.554 \\
(10.408)\end{array}$ \\
\hline Ln(Unemployed) & $\begin{array}{c}-0.102 \\
(0.342)\end{array}$ & $\begin{array}{c}-1.010^{* * *} \\
(0.309)\end{array}$ & $\begin{array}{c}1.027 \\
(0.666)\end{array}$ & $\begin{array}{c}-0.598^{* *} \\
(0.287)\end{array}$ \\
\hline Ln(State Employed) & $\begin{array}{c}1.522 \\
(1.478)\end{array}$ & $\begin{array}{c}3.278^{* *} \\
(1.335)\end{array}$ & $\begin{array}{l}-2.189 \\
(2.875)\end{array}$ & $\begin{array}{c}1.696 \\
(1.241)\end{array}$ \\
\hline Ln(Privately Employed) & $\begin{array}{c}1.677 \\
(1.535)\end{array}$ & $\begin{array}{c}4.876^{* * *} \\
(1.387)\end{array}$ & $\begin{array}{c}0.981 \\
(2.986)\end{array}$ & $\begin{array}{l}2.207^{*} \\
(1.289)\end{array}$ \\
\hline $\operatorname{Ln}$ (Out of the Labor Force) & $\begin{array}{l}-4.691^{*} \\
(2.870)\end{array}$ & $\begin{array}{c}-7.780^{* * *} \\
(2.593)\end{array}$ & $\begin{array}{c}1.698 \\
(5.584)\end{array}$ & $\begin{array}{c}-5.371^{* *} \\
(2.410)\end{array}$ \\
\hline Integral CPI*Ln(Unemployed) & $\begin{array}{c}1.095 \\
(0.850)\end{array}$ & $\begin{array}{c}3.032^{* * *} \\
(0.768)\end{array}$ & $\begin{array}{l}-2.214 \\
(1.654)\end{array}$ & $\begin{array}{c}2.055^{* * *} \\
(0.714)\end{array}$ \\
\hline Integral CPI*Ln(State Employed) & $\begin{array}{l}-3.572 \\
(3.453)\end{array}$ & $\begin{array}{c}-8.351^{* * *} \\
(3.119)\end{array}$ & $\begin{array}{c}6.953 \\
(6.716)\end{array}$ & $\begin{array}{l}-4.310 \\
(2.899)\end{array}$ \\
\hline Integral CPI*Ln(Privately Employed) & $\begin{array}{l}-4.034 \\
(3.186)\end{array}$ & $\begin{array}{c}-9.211^{* * *} \\
(2.878)\end{array}$ & $\begin{array}{c}0.740 \\
(6.197)\end{array}$ & $\begin{array}{l}-4.105 \\
(2.675)\end{array}$ \\
\hline Integral CPI*Ln(Out of the Labor Force) & $\begin{array}{c}8.397 \\
(5.804)\end{array}$ & $\begin{array}{c}15.178^{* * *} \\
(5.244)\end{array}$ & $\begin{array}{c}-7.510 \\
(11.291)\end{array}$ & $\begin{array}{c}11.275^{* *} \\
(4.874)\end{array}$ \\
\hline Ln (Real GRP per capita) & $\begin{array}{c}0.546^{* * *} \\
(0.146)\end{array}$ & $\begin{array}{c}0.082 \\
(0.131)\end{array}$ & $\begin{array}{c}-0.298 \\
(0.283)\end{array}$ & $\begin{array}{c}0.032 \\
(0.122)\end{array}$ \\
\hline Ln (Number of Students) & $\begin{array}{c}0.071 \\
(0.099)\end{array}$ & $\begin{array}{c}0.298^{* * *} \\
(0.090)\end{array}$ & $\begin{array}{c}-0.476^{* *} \\
(0.193)\end{array}$ & $\begin{array}{l}-0.021 \\
(0.083)\end{array}$ \\
\hline Ln (Number of Pensioners) & $\begin{array}{c}1.637^{* * *} \\
(0.542)\end{array}$ & $\begin{array}{c}0.387 \\
(0.490)\end{array}$ & $\begin{array}{c}-2.422^{* *} \\
(1.055)\end{array}$ & $\begin{array}{c}-0.031 \\
(0.455)\end{array}$ \\
\hline Ln (Number of Registered Voters) & $\begin{array}{c}-0.382 \\
(0.431)\end{array}$ & $\begin{array}{l}-0.125 \\
(0.389)\end{array}$ & $\begin{array}{c}2.662^{* * *} \\
(0.838)\end{array}$ & $\begin{array}{c}0.473 \\
(0.362)\end{array}$ \\
\hline Share of Urban Population & $\begin{array}{c}0.664 \\
(0.411)\end{array}$ & $\begin{array}{l}-0.326 \\
(0.371)\end{array}$ & $\begin{array}{c}4.689^{* * * *} \\
(0.799)\end{array}$ & $\begin{array}{c}1.031^{* * *} \\
(0.345)\end{array}$ \\
\hline Moscow & $\begin{array}{c}0.525^{* *} \\
(0.247)\end{array}$ & $\begin{array}{c}0.078 \\
(0.223)\end{array}$ & $\begin{array}{c}1.263^{* * *} \\
(0.480)\end{array}$ & $\begin{array}{c}0.670^{* * *} \\
(0.207)\end{array}$ \\
\hline Constant & $\begin{array}{l}-8.054 \\
(6.647)\end{array}$ & $\begin{array}{c}-13.686^{* *} \\
(6.006)\end{array}$ & $\begin{array}{c}-8.805 \\
(12.930)\end{array}$ & $\begin{array}{l}-2.710 \\
(5.581)\end{array}$ \\
\hline Number of observations & 156 & 156 & 156 & 156 \\
\hline "R-squared" & 0,274 & 0,468 & 0,445 & 0,396 \\
\hline $\mathrm{BIC}$ & \multicolumn{4}{|c|}{$\frac{0,400}{631,346}$} \\
\hline
\end{tabular}

Source: author's calculations. Notes. Voting district is used as an unit of observation. During the 2003 parliamentary elections there were 225 votng districts in total. The number of observations is reduced due to the absence of data on corruption. Columns present the results for a particular group of party "ies. Explanatory variables are given in rows. Standard errors are in parantheses. ***, and *** stand for $10 \%, 5 \%$, and $1 \%$ significance levels, respectively. The choice of SUR is justified since the Breusch-Pagan test for independent equations $\left(\mathrm{chi}^{2}(6)=99.544^{* * *}\right)$ rejects the null hypothesis of independence of residuals across the equations. 
Table 8a. Sensitivity Check for the Estimation Results from the 2003 (Both State Capture Index and Integral CPI are Included)

\begin{tabular}{lcccc}
\hline \hline & Party of Power & Anti-Reform & Pro-Reform & Protest Voting \\
\hline & $(1)$ & $(2)$ & $(3)$ & $(4)$ \\
\hline State Capture & 0.076 & -0.302 & -0.536 & $-0.667^{* * *}$ \\
& $(0.305)$ & $(0.283)$ & $(0.593)$ & $(0.263)$ \\
Integral CPI & $-0.537^{* * *}$ & $-0.492^{* * *}$ & -0.113 & $-0.367^{* * *}$ \\
& $(0.142)$ & $(0.132)$ & $(0.276)$ & $(0.122)$ \\
Ln(Unemployed) & $0.345^{* * *}$ & $0.287^{* *}$ & $0.460^{*}$ & $0.337^{* * *}$ \\
& $(0.131)$ & $(0.122)$ & $(0.255)$ & $(0.113)$ \\
Ln(State Employed) & -0.012 & -0.401 & -0.439 & -0.157 \\
& $(0.494)$ & $(0.459)$ & $(0.961)$ & $(0.425)$ \\
Ln(Privately Employed) & -0.227 & 0.473 & 0.886 & 0.455 \\
& $(0.426)$ & $(0.396)$ & $(0.828)$ & $(0.367)$ \\
Ln(Out of the Labor Force) & -1.078 & 0.065 & 0.846 & -0.780 \\
& $(0.979)$ & $(0.909)$ & $(1.903)$ & $(0.843)$ \\
Ln (Real GRP per capita) & $0.495^{* * *}$ & 0.055 & -0.141 & $0.281^{* *}$ \\
& $(0.136)$ & $(0.126)$ & $(0.264)$ & $(0.117)$ \\
Ln (Number of Students) & 0.038 & -0.043 & $-0.648^{* * *}$ & $-0.308^{* * *}$ \\
& $(0.130)$ & $(0.120)$ & $(0.252)$ & $(0.112)$ \\
Ln (Number of Pensioners) & $1.542^{* * *}$ & -0.390 & $-3.450^{* * *}$ & -0.182 \\
& $(0.533)$ & $(0.495)$ & $(1.036)$ & $(0.459)$ \\
Ln (Number of Registered Voters) & -0.219 & 0.084 & $2.208^{* * *}$ & $0.825^{* *}$ \\
Share of Urban Population & $(0.427)$ & $(0.397)$ & $(0.830)$ & $(0.361)$ \\
Moscow & 0.547 & $-0.816^{* *}$ & $3.951^{* * *}$ & $0.924^{* * *}$ \\
Constant & $(0.378)$ & $(0.351)$ & $(0.735)$ & $(0.326)$ \\
& $0.658^{* * *}$ & $0.533^{* *}$ & $1.398^{* * *}$ & $1.106^{* * *}$ \\
Number of observations & $(0.240)$ & $(0.223)$ & $(0.467)$ & $(0.207)$ \\
"R-squared" BIC & $-4.552^{*}$ & 0.505 & -3.190 & $-4.212^{*}$ \\
\hline Sour* & $(2.648)$ & $(2.460)$ & $(5.147)$ & $(2.280)$ \\
\hline
\end{tabular}

Source: author's calculations. Notes. Voting district is used as an unit of observation. During the 2003 parliamentary elections there were 225 votng districts in total. The number of observations is reduced due to the absence of data on corruption. Columns present the results for a particular group of parties. Explanatory variables are given in rows. Standard errors are in parentheses. ***, and *** stand for $10 \%, 5 \%$, and $1 \%$ significance levels, respectively. The choice of SUR is justified since the Breusch-Pagan test for independent equations $\left(\mathrm{chi}^{2}(6)=96.412^{* * *}\right)$ rejects the null hypothesis of independence of residuals across the equations. 
Table 9a. Sensitivity Check for the Estimation Results from the 1999 (State Capture Index is Used to Control for Corruption)

\begin{tabular}{|c|c|c|c|c|}
\hline & Party of Power & Anti-Reform & Pro-Reform & Protest Voting \\
\hline & $(1)$ & $(2)$ & $(3)$ & $(4)$ \\
\hline State Capture & $\begin{array}{c}7.193^{* * * *} \\
(2.564)\end{array}$ & $\begin{array}{c}7.831^{* * * *} \\
(2.643)\end{array}$ & $\begin{array}{l}-0.782 \\
(2.931)\end{array}$ & $\begin{array}{l}-0.580 \\
(1.628)\end{array}$ \\
\hline Ln(Unemployed) & $\begin{array}{c}0.094 \\
(0.262)\end{array}$ & $\begin{array}{c}0.542^{* *} \\
(0.270)\end{array}$ & $\begin{array}{c}1.089^{* * *} \\
(0.299)\end{array}$ & $\begin{array}{c}0.926^{* * *} \\
(0.166)\end{array}$ \\
\hline Ln(State Employed) & $\begin{array}{c}0.408 \\
(0.493)\end{array}$ & $\begin{array}{c}-0.862^{*} \\
(0.508)\end{array}$ & $\begin{array}{c}-1.500^{* * * *} \\
(0.564)\end{array}$ & $\begin{array}{c}-1.158^{* * *} \\
(0.313)\end{array}$ \\
\hline Ln(Privately Employed) & $\begin{array}{l}-0.354 \\
(0.259)\end{array}$ & $\begin{array}{c}-0.504^{*} \\
(0.267)\end{array}$ & $\begin{array}{l}-0.118 \\
(0.296)\end{array}$ & $\begin{array}{l}-0.003 \\
(0.164)\end{array}$ \\
\hline Ln(Out of the Labor Force) & $\begin{array}{c}-0.181 \\
(0.760)\end{array}$ & $\begin{array}{l}1.495^{*} \\
(0.784)\end{array}$ & $\begin{array}{c}0.738 \\
(0.870)\end{array}$ & $\begin{array}{c}1.766^{* * *} \\
(0.483)\end{array}$ \\
\hline State Capture*Ln(Unemployed) & $\begin{array}{c}0.375 \\
(0.602)\end{array}$ & $\begin{array}{l}-0.653 \\
(0.621)\end{array}$ & $\begin{array}{c}-2.850^{* * *} \\
(0.689)\end{array}$ & $\begin{array}{c}-2.228^{* * *} \\
(0.382)\end{array}$ \\
\hline State Capture*Ln(State Employed) & $\begin{array}{c}-0.248 \\
(1.205)\end{array}$ & $\begin{array}{c}-0.224 \\
(1.241)\end{array}$ & $\begin{array}{c}3.350^{* *} \\
(1.377)\end{array}$ & $\begin{array}{c}3.645^{* * *} \\
(0.765)\end{array}$ \\
\hline State Capture*Ln(Privately Employed) & $\begin{array}{l}-0.794 \\
(0.613)\end{array}$ & $\begin{array}{l}-0.671 \\
(0.632)\end{array}$ & $\begin{array}{l}-0.535 \\
(0.701)\end{array}$ & $\begin{array}{c}-0.635^{*} \\
(0.389)\end{array}$ \\
\hline State Capture* $\operatorname{Ln}($ Out of the Labor Force) & $\begin{array}{l}-1.104 \\
(1.235)\end{array}$ & $\begin{array}{c}-0.250 \\
(1.273)\end{array}$ & $\begin{array}{l}-0.444 \\
(1.412)\end{array}$ & $\begin{array}{c}-1.636^{* *} \\
(0.784)\end{array}$ \\
\hline Ln(Real GRP per capita) & $\begin{array}{c}-0.211^{* *} \\
(0.090)\end{array}$ & $\begin{array}{c}-0.409^{* * *} \\
(0.092)\end{array}$ & $\begin{array}{c}0.048 \\
(0.103)\end{array}$ & $\begin{array}{c}-0.152^{* * *} \\
(0.057)\end{array}$ \\
\hline Ln(Students) & $\begin{array}{c}0.252^{* * *} \\
(0.091)\end{array}$ & $\begin{array}{c}0.115 \\
(0.093)\end{array}$ & $\begin{array}{c}0.138 \\
(0.104)\end{array}$ & $\begin{array}{c}-0.349^{* * *} \\
(0.101)\end{array}$ \\
\hline Ln(Pensioners) & $\begin{array}{c}0.898^{* * *} \\
(0.335)\end{array}$ & $\begin{array}{c}0.251 \\
(0.345)\end{array}$ & $\begin{array}{c}-0.114 \\
(0.383)\end{array}$ & $\begin{array}{c}-0.810^{* * *} \\
(0.213)\end{array}$ \\
\hline Ln(Number of Registered Voters) & $\begin{array}{c}0.004 \\
(0.051)\end{array}$ & $\begin{array}{c}-0.005 \\
(0.052)\end{array}$ & $\begin{array}{c}0.001 \\
(0.058)\end{array}$ & $\begin{array}{c}-0.010 \\
(0.032)\end{array}$ \\
\hline Share of Urban Population & $\begin{array}{c}-0.876^{* * *} \\
(0.281)\end{array}$ & $\begin{array}{c}-2.158^{* * *} \\
(0.289)\end{array}$ & $\begin{array}{c}1.513^{* * *} \\
(0.321)\end{array}$ & $\begin{array}{c}0.389^{* *} \\
(0.178)\end{array}$ \\
\hline Moscow & $\begin{array}{c}1.334^{* * *} \\
(0.213)\end{array}$ & $\begin{array}{c}0.872^{* * *} \\
(0.220)\end{array}$ & $\begin{array}{c}0.534^{* *} \\
(0.244)\end{array}$ & $\begin{array}{c}0.427^{* * *} \\
(0.135)\end{array}$ \\
\hline Constant & $\begin{array}{l}-1.973 \\
(4.293)\end{array}$ & $\begin{array}{c}-8.944^{* *} \\
(4.424)\end{array}$ & $\begin{array}{l}-5.049 \\
(4.908)\end{array}$ & $\begin{array}{c}-10.755^{* * *} \\
(2.725)\end{array}$ \\
\hline Number of observations & 205 & 205 & 205 & 205 \\
\hline "R-squared" & 0,373 & 0,521 & 0,401 & 0,324 \\
\hline $\mathrm{BIC}$ & \multicolumn{4}{|c|}{682,263} \\
\hline \multicolumn{5}{|c|}{$\begin{array}{l}\text { Source: author's calculations. Notes. Voting district is used as an unit of observation. During the } 1999 \\
\text { parliamentary elections there were } 224 \text { votng districts in total. The number of observations is reduced due to } \\
\text { the absence of data on corruption. Columns present the results for a particular group of parties. Explanatory } \\
\text { variables are given in rows. Standard errors are in parantheses. ***, and *** stand for } 10 \%, 5 \% \text {, and } 1 \% \\
\text { significance levels, respectively. The choice of SUR is justified since the Breusch-Pagan test for independent }\end{array}$} \\
\hline
\end{tabular}




\section{Working Paper Series}

ISSN 1211-3298

Registration No. (Ministry of Culture): E 19443

Individual researchers, as well as the on-line and printed versions of the CERGE-EI Working Papers (including their dissemination) were supported from the European Structural Fund (within the Operational Programme Prague Adaptability), the budget of the City of Prague, the Czech Republic's state budget and the following institutional grants:

- Center of Advanced Political Economy Research [Centrum pro pokročilá politickoekonomická studia], No. LC542, (2005-2010);

- Economic Aspects of EU and EMU Entry [Ekonomické aspekty vstupu do Evropské unie a Evropské měnové unie], No. AVOZ70850503, (2005-2010);

- Economic Impact of European Integration on the Czech Republic [Ekonomické dopady evropské integrace na ČR], No. MSM0021620846, (2005-2011);

Specific research support and/or other grants the researchers/publications benefited from are acknowledged at the beginning of the Paper.

\section{(c) Olga Popova, 2010}

All rights reserved. No part of this publication may be reproduced, stored in a retrieval system or transmitted in any form or by any means, electronic, mechanical or photocopying, recording, or otherwise without the prior permission of the publisher.

Published by

Charles University in Prague, Center for Economic Research and Graduate Education (CERGE) and

Economics Institute ASCR, v. v. i. (EI)

CERGE-El, Politických vězňů 7, 11121 Prague 1, tel.: +420 224005 153, Czech Republic.

Printed by CERGE-EI, Prague

Subscription: CERGE-EI homepage: http://www.cerge-ei.cz

Phone: + 420224005153

Email: office@cerge-ei.cz

Web: http://www.cerge-ei.cz

Editor: Michal Kejak

Editorial board: Jan Kmenta, Randall Filer, Petr Zemčík

The paper is available online at http://www.cerge-ei.cz/publications/working_papers/.

ISBN 978-80-7343-229-4 (Univerzita Karlova. Centrum pro ekonomický výzkum a doktorské studium)

ISBN 978-80-7344-219-4 (Národohospodářský ústav AV ČR, v. v. i.) 
CERGE-EI

P.O.BOX 882

Politických vězňů 7

11121 Praha 1

Czech Republic http://www.cerge-ei.cz 